LBNL-44314

\title{
Energy Use and Energy Intensity of the U.S. Chemical Industry
}

\author{
Ernst Worrell, Dian Phylipsen, Dan Einstein, and Nathan Martin
}

\author{
Energy Analysis Department \\ Environmental Energy Technologies Division \\ Ernest Orlando Lawrence Berkeley National Laboratory \\ University of California \\ Berkeley, California 94720
}

April 2000

This work was supported by the Climate Protection Division, Office of Air and Radiation, U.S.

Environmental Protection Agency through the U.S. Department of Energy under Contract No. DE-AC03-76SF00098. 



\title{
Energy Use and Energy Intensity of the U.S. Chemical Industry
}

\author{
Ernst Worrell, Dian Phylipsen, Dan Einstein, Nathan Martin \\ Energy Analysis Department \\ Environmental Energy Technologies Division \\ Ernest Orlando Lawrence Berkeley National Laboratory
}

April 2000

\begin{abstract}
The U.S. chemical industry is the largest in the world, and responsible for about $11 \%$ of the U.S. industrial production measured as value added. It consumes approximately $20 \%$ of total industrial energy consumption in the U.S. (1994), and contributes in similar proportions to U.S. greenhouse gas emissions. Surprisingly, there is not much information on energy use and energy intensity in the chemical industry available in the public domain. This report provides detailed information on energy use and energy intensity for the major groups of energy-intensive chemical products.

Ethylene production is the major product in terms of production volume of the petrochemical industry. The petrochemical industry (SIC 2869) produces a wide variety of products. However, most energy is used for a small number of intermediate compounds, of which ethylene is the most important one. Based on a detailed assessment we estimate fuel use for ethylene manufacture at $520 \mathrm{PJ}$ (LHV), excluding feedstock use. Energy intensity is estimated at $26 \mathrm{GJ} /$ tonne ethylene (LHV), excluding feedstocks.

The nitrogenous fertilizer production is a very energy intensive industry, producing a variety of fertilizers and other nitrogen-compounds. Ammonia is the most important intermediate chemical compound, used as basis for almost all products. Fuel use is estimated at 268 PJ (excluding feedstocks) while $368 \mathrm{PJ}$ natural gas is used as feedstock. Electricity consumption is estimated at 14 PJ. We estimate the energy intensity of ammonia manufacture at $39.3 \mathrm{GJ} /$ tonne (including feedstocks, HHV) and $140 \mathrm{kWh} /$ tonne, resulting in a specific primary energy consumption of $40.9 \mathrm{GJ} /$ tonne (HHV), equivalent to $37.1 \mathrm{GJ} /$ tonne (LHV). Excluding natural gas use for feedstocks the primary energy consumption is estimated at $16.7 \mathrm{GJ} /$ tonne (LHV).

The third most important product from an energy perspective is the production of chlorine and caustic soda. Chlorine is produced through electrolysis of a salt-solution. Chlorine production is the main electricity consuming process in the chemical industry, next to oxygen and nitrogen production. We estimate final electricity use at $173 \mathrm{PJ}(48 \mathrm{TWh})$ and fuel use of $38 \mathrm{PJ}$. Total primary energy consumption is estimated at $526 \mathrm{PJ}$ (including credits for hydrogen export). The energy intensity is estimated at an electricity consumption of $4380 \mathrm{kWh} /$ tonne chlorine and fuel consumption of $3.45 \mathrm{GJ} /$ tonne chlorine, where all energy use is allocated to chlorine production. Assuming an average power generation efficiency of 33\% the primary energy consumption is estimated at $47.8 \mathrm{GJ} /$ tonne chlorine (allocating all energy use to chlorine).
\end{abstract}




\section{Contents}

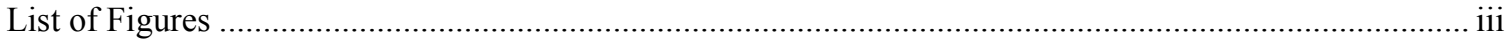

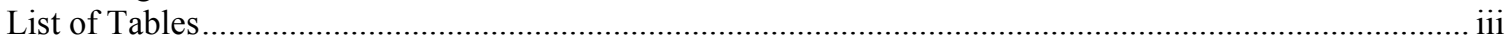

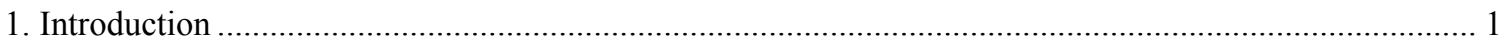

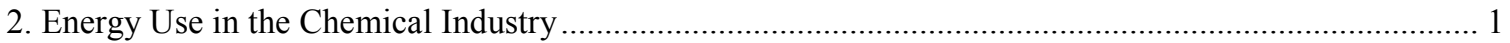

2.1 Industrial organic chemicals, not elswhere classified (SIC 2869) .......................................... 3

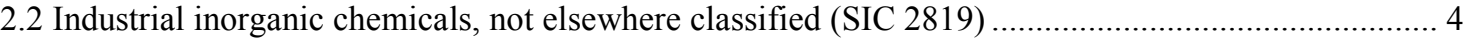

2.3 Plastic Materials and Resins (SIC 2821)

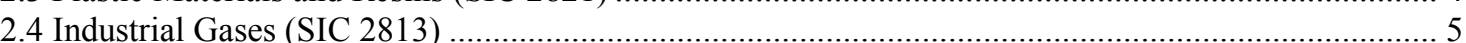

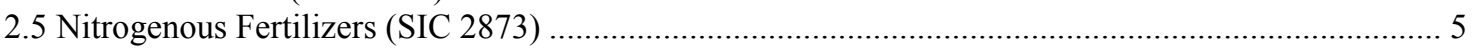

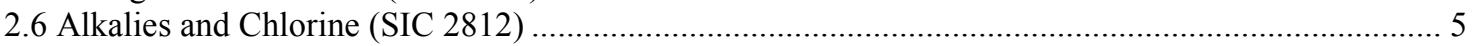

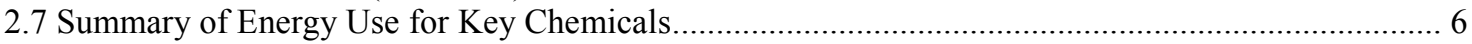

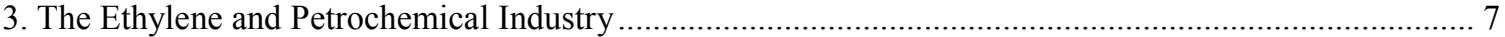

3.2. Process Description

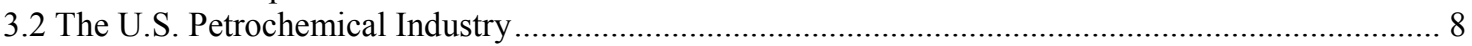

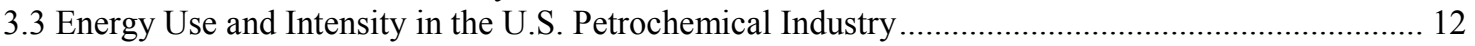

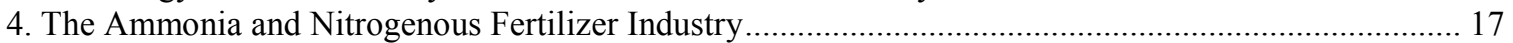

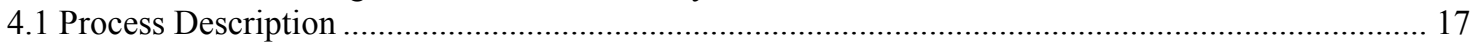

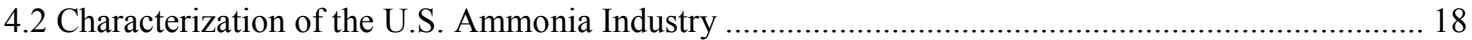

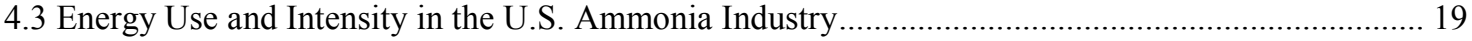

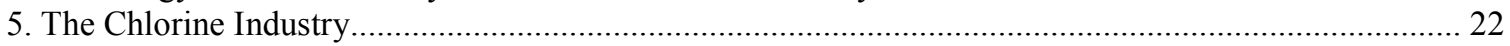

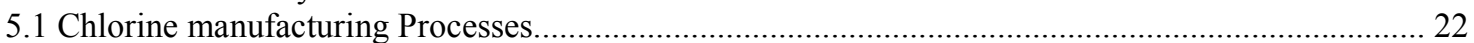

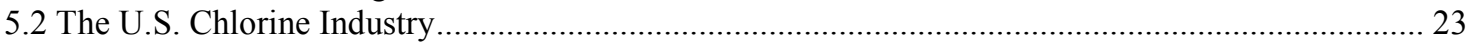

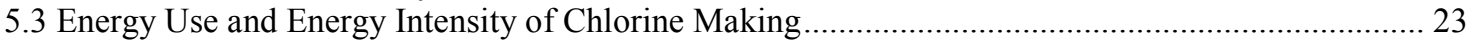

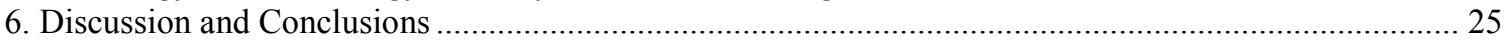

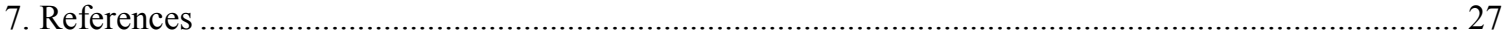

\section{List of Figures}

Figure 1. Carbon Dioxide Emissions from Energy Use, and Value Added for U.S. Chemicals, 1985-1994..2

Figure 2. Share of Primary Energy Use, Shipments, Value Added, Carbon Dioxide $\left(\mathrm{CO}_{2}\right)$ Emissions, for

Selected U.S. Chemicals Subsectors, 1994 .............................................................. 3

Figure 3. Process routes for the production of ethylene and its co-products ................................... 8

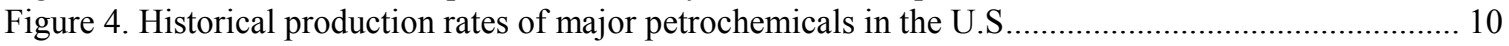

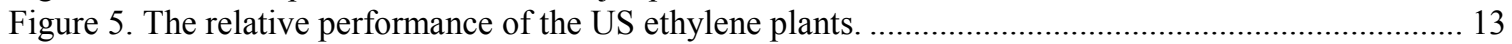

Figure 6. Historical U.S. production of ammonia, and some major fertilizers, expressed in 1000 metric

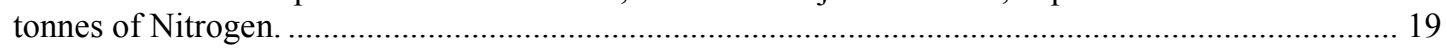

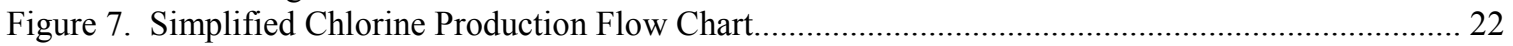

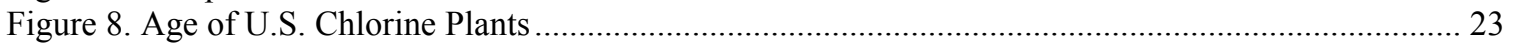

\section{List of Tables}

Table 1. Primary Energy Use (excluding feedstocks), Carbon Dioxide $\left(\mathrm{CO}_{2}\right)$ Emissions from Energy Use, and Value Added for U.S. Chemicals and U.S. Manufacturing in 1994

Table 2. Primary Energy Use, Shipments, Value Added, Carbon Dioxide $\left(\mathrm{CO}_{2}\right)$ Emissions, for Selected

U.S. Chemicals Subsectors in 1994

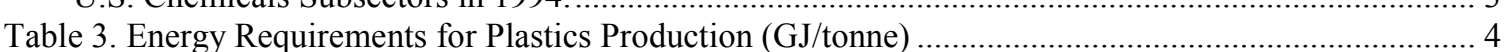

Table 4. Average Annual Growth Rate of selected U.S. plastic products .......................................... 5

Table 5. Energy Consumption for Chlorine production with Mercury, Diaphragm, and Membrane Cells

(kWh/tonne and GJ/tonne) and estimated shares in the U.S. in 1994...

Table 6. 1994 Estimated U.S. Energy Consumption for Selected Key Chemicals................................ 8

Table 8. The US ethylene capacity and feedstock input compared to other major producers ....................9.9

Table 9. Estimated feedstock input for the U.S. and total world ethylene production capacity in 1995 (as \%

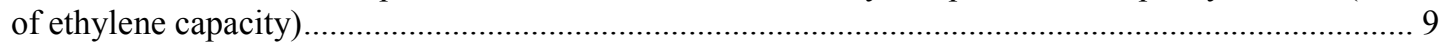

Table 10. Cash margins for ethylene production for different feedstocks during August 1998 ................ 11

Table 11. The energy efficiency index for several regions according to the Solomon survey ................. 14

Table 12. Detailed breakdown of energy consumption in ethane cracking. 
Table 13. Breakdown of primary specific energy consumption (SEC) for ethylene production for different

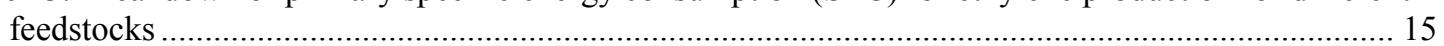

Table 14. Detailed breakdown of energy consumption for a naphtha cracker and a flexible cracker ......... 15

Table 15. Estimated energy consumption by process step in U.S. ethylene production.............................. 16

Table 16. Estimated energy balance for U.S. ammonia manufacturing (1996) ...................................... 21

Table 17. Chlorine Industry Energy Use and Carbon Dioxide Emissions. ............................................. 24 


\section{Introduction}

In 1994 the manufacturing sector consumed 26 EJ of primary energy in the United States, almost one-quarter of all energy consumed that year (U.S. DOE, EIA 1997). ${ }^{1}$ Within manufacturing, a subset of raw materials transformation industries (primary metals, pulp and paper, cement, chemicals, petroleum refining) require significantly more energy to produce than other manufactured products.

In this report we study the energy consumption and intensity in the U.S. chemical industry. The chemical industry is one of the largest energy consuming industrial sub-sectors in the U.S. The chemical industry is complex, encompassing the production of over 50,000 chemical compounds. The industry is also an important part of the global economy, accounting for approximately $7 \%$ of global income and 9\% of international trade (WEC, 1995).

The chemical industry produces many intermediate compounds that are used as the basis for many chemical products. For example, ethylene, one of the most important bulk chemicals from an energy point-of-view, is used to produce products varying from solvents to plastics. Also, many processes in the chemical industry produce different co-products. This makes energy analysis of the chemical industry more complicated compared to other industries.

In this report we study the energy consumption of the U.S. chemical industry. We assess current energy consumption and production levels. This information has been used to develop a detailed baseline energy consumption and intensity for three of the most energy intensive and energy consuming chemicals, i.e. ethylene, ammonia and chlorine. We focus on the year 1994, as this is the last year for which the Energy Information Administration has published energy consumption data (the Manufacturing Energy Consumption Survey 1994). No detailed studies on the energy intensity of the U.S. chemical industry have recently been published. The energy intensity baseline will be used for future detailed analyses of the potential of energy efficiency improvement, and carbon dioxide emission reduction in the U.S. chemicals industry.

We start with a discussion of the major energy consuming sub-sectors and products in the chemical industry (Chapter 2). This is followed by detailed energy analyses of energy use and energy intensities of three major bulk chemicals, i.e. ethylene (Chapter 3), ammonia and nitrogenous fertilizers (Chapter 4) and chlorine (chapter 5). The reliability and usefulness of the results are discussed in Chapter 6.

\section{Energy Use in the Chemical Industry}

Primary energy use by and associated $\mathrm{CO}_{2}$ emissions from the U.S. chemicals sector (SIC 28) were roughly $20 \%$ of total manufacturing primary energy use and $\mathrm{CO}_{2}$ emissions in 1994 . The chemical industry produced $11 \%$ of total manufacturing value added in the U.S. (see Table 1). Figure 1 depicts carbon dioxide emissions from energy use and value added for SIC 28 between 1985 and $1994 .^{2}$ Emissions have grown at an annual rate of $2.9 \%$ during that period, while value added has increased at a slightly faster rate of $4.6 \%$.

\footnotetext{
${ }^{1}$ In this report we will use SI-units. To convert from GJ to MBtu, multiply by 0.95 ; to convert from metric tons to short tons, multiply by 1.1 ; to convert from $\mathrm{GJ} /$ metric ton to MBtu/short ton, multiply by 0.86 .

${ }^{2}$ Carbon emissions estimates include fuels and electricity for energy consumption and feedstocks used for ammonia manufacture less carbon embedded in urea. For other chemical products most of the carbon is not emitted as $\mathrm{CO}_{2}$. Emissions factors are given by EIA (1996).
} 
Table 1. Primary Energy Use (excluding feedstocks), Carbon Dioxide ( $\left.\mathrm{CO}_{2}\right)$ Emissions from Energy Use, and Value Added for U.S. Chemicals and U.S. Manufacturing in 1994. Source: EIA (1997); EIA (1996); BOC (1998).

\begin{tabular}{|l|r|r|r|}
\hline Sector & $\begin{array}{l}\text { Primary } \\
\text { Energy } \\
(\mathrm{Tbtu})\end{array}$ & $\begin{array}{l}\mathrm{CO}_{2} \text { Emissions } \\
(\mathrm{MtC})\end{array}$ & $\begin{array}{l}\text { Value Added } \\
\text { (Billion \$1992) }\end{array}$ \\
\hline Chemicals (SIC 28) & 5,141 & 77 & 172 \\
Manufacturing total & 26,047 & 398 & 1,570 \\
Share of SIC 28 to Total Manufacturing & $20 \%$ & $19 \%$ & $11 \%$ \\
\hline
\end{tabular}

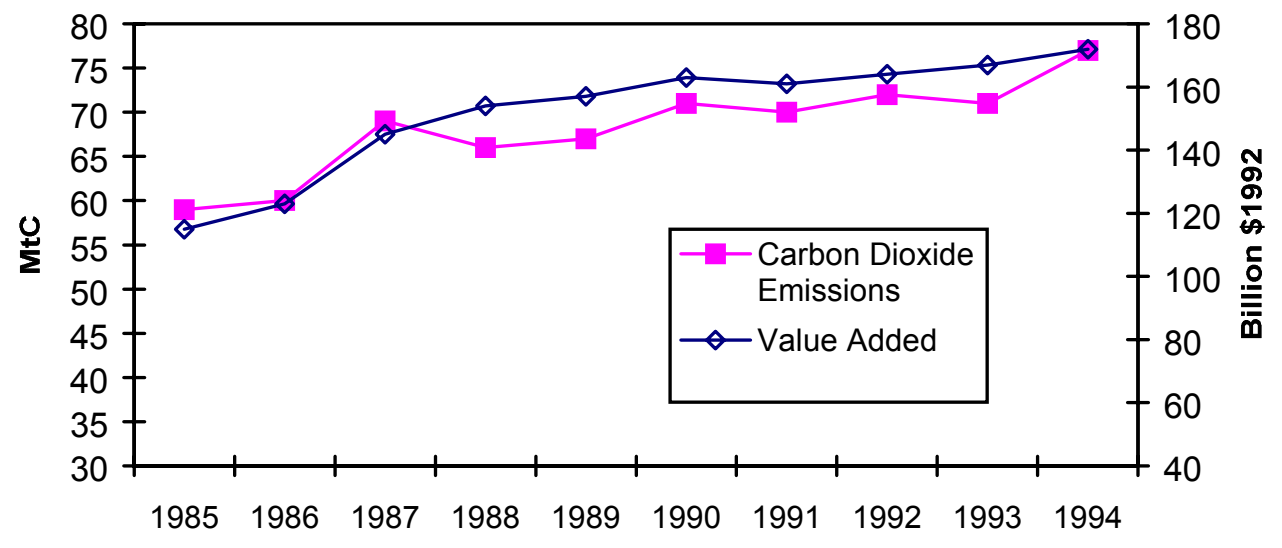

Figure 1. Carbon Dioxide Emissions from Energy Use, and Value Added for U.S. Chemicals, 1985-1994. Source: EIA (1997); EIA (1996); EIA (1994); EIA (1991); EIA (1988) BOC (1998).

The U.S. Manufacturing Energy Consumption Survey provides energy consumption information for selected chemicals subsectors. The subsectors that accounted for the largest share of primary energy (see also Figure 2 and Table 2) in 1994 were: industrial organic chemicals not elsewhere classified (SIC 2869), industrial inorganic chemicals not elswhere classified (SIC 2819), plastic materials and resins (SIC 2821), and nitrogenous fertilizers (SIC 2873), industrial gases (SIC 2813) and alkalies and chlorine (SIC 2812). With the exception of plastics and resins, the primary energy requirements associated the production of one dollar of shipped product are three to nine times greater than for the average of the chemicals sector as a whole. This demonstrates that there are several highly energy-intensive production processes within these subsectors that are often used to produce intermediate chemicals. These subsectors will be described in greater detail below. 


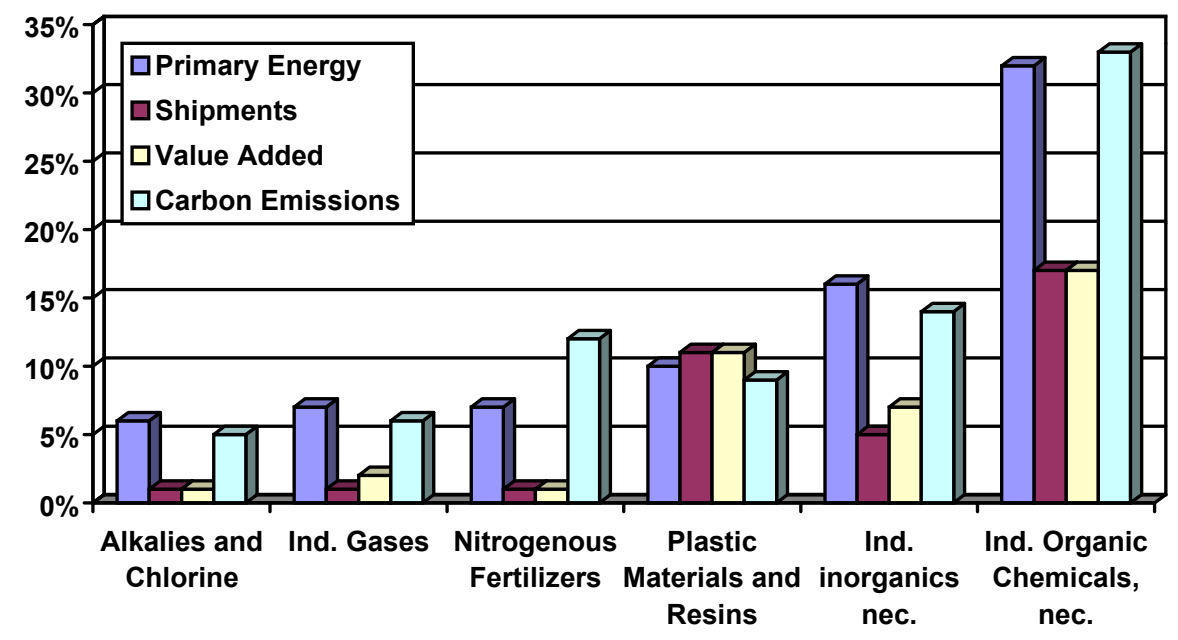

Figure 2. Share of Primary Energy Use, Shipments, Value Added, Carbon Dioxide $\left(\mathrm{CO}_{2}\right)$ Emissions, for Selected U.S. Chemicals Subsectors, 1994. Source: EIA (1997); EIA (1996); BEA, (1998); BOC (1998).

Table 2. Primary Energy Use, Shipments, Value Added, Carbon Dioxide $\left(\mathrm{CO}_{2}\right)$ Emissions, for Selected U.S. Chemicals Subsectors in 1994. Sources: EIA (1997); EIA (1996); BEA (1998), BOC (1998). Energy use and emission data exclude feedstocks.

\begin{tabular}{|l|c|c|c|c|c|}
\hline Chemical Subsector & $\begin{array}{c}\text { SIC } \\
\text { Code }\end{array}$ & $\begin{array}{c}\text { Primary } \\
\text { Energy } \\
\text { (PJ) }\end{array}$ & $\begin{array}{c}\text { Shipments } \\
\text { (Millions } \\
\mathbf{\$ 1 9 9 2}\end{array}$ & $\begin{array}{c}\text { Value Added } \\
\text { (Millions } \\
\mathbf{\$ 1 9 9 2}\end{array}$ & $\begin{array}{c}\mathbf{C O}_{2} \text { Emissions } \\
\text { from Energy Use } \\
\text { (MtC) }\end{array}$ \\
\hline Industrial Organics, nec & 2869 & 1,653 & 53,983 & 22,623 & 25 \\
Industrial Inorganics, nec & 2819 & 830 & 15,638 & 9,491 & 11 \\
Plastic Materials and Resins & 2821 & 518 & 35,307 & 14,307 & 7 \\
Nitrogenous Fertilizers & 2873 & 344 & 3,648 & 1,689 & 10 \\
Industrial Gases & 2813 & 364 & 3,128 & 2,188 & 4 \\
Alkalies and Chlorine & 2812 & 286 & 2,034 & 951 & 4 \\
Others & & 1,146 & 203,316 & 120,796 & 16 \\
\hline Total Chemicals & $\mathbf{2 8}$ & $\mathbf{5 , 1 4 1}$ & $\mathbf{3 1 7 , 0 5 4}$ & $\mathbf{1 7 2 , 0 4 5}$ & $\mathbf{7 7}$ \\
\hline
\end{tabular}

\subsection{Industrial organic chemicals, not elswhere classified (SIC 2869)}

As noted above, industrial organic chemicals not elsewhere classified accounted for the largest share of energy use in the chemicals sector as a whole in 1994 (33\%). From an energy perspective, some of the key chemical products included within this category are ethylene and other steam cracking derivatives (propylene and butadiene) and methanol.

Ethylene and its derivatives are important petrochemicals in the U.S. economy, and are feedstocks for many plastics and resins products produced in SIC 2821 (see below) as well as fibers and detergents. In 1994, ethylene was the fourth largest chemical produced while propylene was the seventh largest chemical produced (Chemical and Engineering News, 1995). The U.S. is currently the worlds largest ethylene producer accounting for $28 \%$ of world installed capacity (Oil and Gas Journal, 1997. Since 1974, ethylene production has grown by 3\% annually while propylene has grown by over $4 \%$ annually. Propylene has grown more rapidly in the last decade-5\% per year. Overall, however, industrial organic chemicals as a group have grown more slowly (2\% per year) since 1985, due in part to a drop in output in 1996 (Chemical and Engineering News, 1997). 
In ethylene production, hydrocarbon feedstocks (such as ethane or naphtha) are heated in pyrolysis furnaces, separated into gaseous products, and then rapidly cooled, compressed, and purified into final products with the largest energy requirements required in the pyrolysis, refrigeration and rapid cooling (WEC, 1995). Lighter feedstocks such as ethane produce higher ethylene yields. More severe processing conditions (higher temperatures and pressures) used on heavier feedstocks require more energy to crack but also result in a more co-product yields (methane, butadienes, benzene, and toluene) (Phylipsen et al, 1998a). In the US, ethane remains the primary feedstock used in steam cracking, followed by propane, naphtha and gas oil. Chapter 3 describes energy use and energy intensity for ethylene manufacturing in more detail.

Methanol is produced through the reaction of carbon monoxide and hydrogen, with the production of hydrogen being a significant energy use. Methanol demand has been driven up in recent years due to increasing demand for Methyl tertiair-butyl ether (MTBE) as a reformulated gasoline additive. Growth over the last decade has averaged $8.5 \%$ annually. However, MTBE-use in the U.S. will be phased out in the foreseeable future due to water pollution problems associated with MTBE-use. Estimated energy intensity for methanol (including feedstocks) is $38 \mathrm{GJ} /$ tonne with most of the energy use being used for hydrogen production (Lipinsky and Ingham, 1994).

\subsection{Industrial inorganic chemicals, not elsewhere classified (SIC 2819)}

Industrial inorganic chemicals not elsewhere classified accounted for the second largest share of carbon emissions within the US chemicals sector in 1994 (14\%). This category includes a wide variety of inorganic chemicals including sulfuric and hydrochloric acid, potassium fertilizers (potash), alumina, and aluminum oxide. Hydrochloric acid and Potash are produced in bulk quantities and were among the top 40 chemicals produced in the US in 1994.

\subsection{Plastic Materials and Resins (SIC 2821)}

While not as energy-intensive as the production of bulk chemicals, the production of plastic materials in SIC 2821 accounts for a significant share of carbon dioxide emissions $(9 \%$ of chemical industry emissions in 1994) due to primarily the large volume of production. Some of the main plastic products include polyethylene, (low and high density), polypropylene, polystyrene, and polyvinyl chloride. Ethylene (within SIC 2869) is used as a primary feedstock for polyethylene manufacture. Estimates of per ton energy requirements for polymerization processes are shown in Table 3 below. Estimates from Worrell et al (1994a), except for polystyrene, likely reflect best practice levels for the US.

\section{Table 3. Energy Requirements for Plastics Production (GJ/tonne)}

\begin{tabular}{|l|c|c|}
\hline Product & Estimate $1^{*}$ & Estimate $2^{*}$ \\
\hline Polyethylene (LDPE) & 9.3 & 1.6 \\
Polypropylene & 10.5 & 1.2 \\
Polystyrene & 9.3 & 11.3 \\
Polyvinyl Chloride* & 11.6 & 9.9 \\
\hline
\end{tabular}

*Estimate (1) is based on Lipinsky and Wesson (1995); Estimate 2 is based on Worrell et al. (1994a).

Table 4 shows the production growth rates of high and low density polyethylene, polypropylene, polystyrene, and PVC over the last two decades. As table 4 shows, plastics production has grown rapidly at rates of over 3-8\% since 1974, with particularly strong growth in PVC, polypropylene, and high-density polyethylene. Given the continued demand for plastics in a variety of end uses, we expect continued growth in this subsector. 
Table 4. Average Annual Growth Rate of selected U.S. plastic products. Source: Chemical and Engineering News (1985); Chemical and Engineering News (1997).

\begin{tabular}{|l|cc|}
\hline Product & $1974-1996$ & $1985-1996$ \\
\hline Polyethylene - low density & $4.0 \%$ & $4.3 \%$ \\
Polyethylene - high density & $6.9 \%$ & $5.8 \%$ \\
Polypropylene & $7.9 \%$ & $8.0 \%$ \\
Polystyrene & $2.7 \%$ & $3.7 \%$ \\
Polyvinyl Chloride and & $4.7 \%$ & $6.3 \%$ \\
copolymers & & \\
\hline
\end{tabular}

\subsection{Industrial Gases (SIC 2813)}

The production of industrial gases is a relatively energy intensive process, and this sector accounted for $6 \%$ of carbon dioxide emissions from within the chemical sector in 1994. Nitrogen and oxygen production have historically counted for about half the value of shipments in the subsector (Lipinsky and Ingham, 1994) and are typically the second and third largest produced chemicals. These two gases are produced mainly through cryogenic air separation where air is cooled and pressurized until it becomes a liquid with the various gases extracted through fractional distillation. However other technologies are increasingly being used such as pressure swing absorption and membrane separation. Energy consumption for oxygen production has been estimated at $2.0 \mathrm{GJ} /$ tonne (OTA, 1993). Assuming these intensities, energy consumption for these two gases in 1994 would account for over $85 \%$ of SIC 2813. Since 1985 the production of nitrogen and oxygen has grown by over $4 \%$ annually.

\subsection{Nitrogenous Fertilizers (SIC 2873)}

The production of ammonia, a key component in the manufacture of nitrogenous fertilizers, is a highly energy intensive process. Roughly $80 \%$ of ammonia production is used as fertilizer feedstock in the U.S. (Lipinsky and Ingham, 1994). Like methanol, ammonia is produced through the high-pressure synthesis of gases (carbon dioxide, hydrogen, and nitrogen). Ammonia production accounts for over $85 \%$ of the energy consumption in SIC 2873. The production of these products has grown on the order of 1\% annually since 1974.

\subsection{Alkalies and Chlorine (SIC 2812)}

One of the main uses of chlorine (around 30\%) is as an intermediate feedstock for polyvinyl chloride (PVC) which has been growing rapidly over the past decade (Lipinsky and Ingham, 1994). Chlorine is also used as a bleaching agent in pulping operations. The production of chlorine is a highly electricity-intensive process requiring between $3065 \mathrm{kWh} /$ tonne and 3960 $\mathrm{kWh} /$ tonne depending on the cell type (Pletcher and Walsh, 1989). In the process an electric current is used to separate molecules into their constituents. The products of the process include chlorine and caustic soda. Table 5 shows estimated energy consumption for the various cell types. Steam consumption in diaphragm cells is greater since more energy is required to concentrate the brine. We assume a weighted energy intensity of $12.8 \mathrm{GJ} /$ tonne based on the 1994 shares (see Chapter 5). 
Table 5. Energy Consumption for Chlorine production with Mercury, Diaphragm, and Membrane Cells (kWh/tonne and GJ/tonne) and estimated shares in the U.S. in 1994 (percent). See also chapter 5. Electricity is converted to primary energy using a generation efficiency of 33\%. All energy use in Table 5 is allocated to chlorine production. In reality the product-mix consists of approximately $55 \%$ caustic soda and $45 \%$ chlorine (on weight-basis).

\begin{tabular}{|l|l|c|c|c|}
\hline Component & Units & Mercury & Diaphragm & Membrane \\
\hline Steam & GJ/tonne & 0.1 & 2.6 & 0.5 \\
Electricity & $\mathrm{kWh} /$ tonne & 3420 & 3140 & 2720 \\
Total - Primary Energy & GJ/tonne & 37.4 & 36.8 & 30.2 \\
Shares in U.S. (1994) & Percent & $15 \%$ & $75 \%$ & $8 \%$ \\
\hline
\end{tabular}

\subsection{Summary of Energy Use for Key Chemicals}

Table 6 summarizes the energy consumption and estimated energy intensity of the key chemical compounds produced in the U.S. chemical industry. A few chemical products dominate energy use, i.e. ethylene and co-products, ammonia, chlorine and methanol. In the following sections we will assess energy intensities for the production of ethylene, ammonia and chlorine in more detail.

Table 6. 1994 Estimated U.S. final energy consumption (HHV) for selected key chemicals. (including feedstocks)

\begin{tabular}{|l|c|c|c|c|}
\hline Product & $\begin{array}{c}\text { Estimated Final } \\
\text { Energy SEC } \\
\text { (GJ/tonne) }\end{array}$ & $\begin{array}{c}1994 \\
\text { Production } \\
\text { (million tonnes) }\end{array}$ & $\begin{array}{c}\text { Estimated Total } \\
\text { Energy Use in } \\
1994 \\
(\mathrm{PJ})\end{array}$ & $\begin{array}{c}\text { Percent Share of } \\
\text { SIC 28 Energy Use }\end{array}$ \\
\hline Ethylene and co-products & 67.5 & 26.2 & 1768 & $29.3 \%$ \\
Methanol & 38.4 & 4.9 & 188 & $3.1 \%$ \\
Polyethylene & 9.3 & 5.7 & 53 & $0.9 \%$ \\
Polypropylene & 10.5 & 4.4 & 45 & $0.7 \%$ \\
Polyvinyl Chloride & 11.6 & 5.4 & 62 & $1.0 \%$ \\
Polystyrene & 9.3 & 2.6 & 24 & $0.4 \%$ \\
Nitrogen & 1.8 & 28.6 & 49 & $0.8 \%$ \\
Oxygen & 1.8 & 22.7 & 645 & $0.7 \%$ \\
Ammonia & 39.8 & 16.2 & 21 & $10.5 \%$ \\
Urea & 2.8 & 7.6 & 213 & $0.3 \%$ \\
Chlorine & 19.2 & 11.1 & $\mathbf{3 1 1 2}$ & $3.5 \%$ \\
\hline Total & & & $\mathbf{5 1 . 5 \%}$ \\
\hline
\end{tabular}

${ }^{1}$ Co-products include propylene, benzene, and butadiene. SEC reflects energy per ton of all high value products from steam cracking.

${ }^{2}$ The SEC, or Specific Energy Consumption estimates are preliminary. Sources for SEC are as follows: ethylene and co-products (see Chapter 3), methanol and urea (Lipinksy and Ingham, 1994), polyethylene, polypropylene, polyvinyl chloride (Lipinsky and Wesson, 1995), Nitrogen and Oxygen (OTA, 1993), ammonia (see Chapter 4), chlorine (see Chapter 5). Production estimates are from CMA (1996). 


\section{The Ethylene and Petrochemical Industry}

This chapter reflects an in-depth analysis of a part of one of the energy-intensive sub-sectors: the petrochemical. In the petrochemical industry mostly relatively simple organic chemicals are produced such as ethylene, propylene and benzene. These chemicals (some through intermediates, e.g. mono vinyl chloride or styrene) form the building blocks for many products such as plastics, resins, fibers, detergents, etc.

The single most energy-consuming step in the petrochemical industry is the steam cracking of hydrocarbon feedstocks to produce ethylene, propylene, butadiene and aromatics (benzene, toluene and xylenes). Recent estimates of global energy consumption for the production of ethylene and co-products are not available. In 1990 energy consumption was estimated to be about $1 \mathrm{EJ}$ (or $950 \mathrm{TBtu}$, excluding feedstock energy consumption), with ethylene production amounting to 50 Million tonnes (WEC, 1995). By 1997, global ethylene production had risen to 70Mt/a (O\&GJ, 1998). The U.S. is currently the world's largest ethylene producer, accounting for about $28 \%$ of world capacity (Rhodes, 1997).

In section 3.1 we first discuss the major process used to produce ethylene and its co-products, followed by a discussion of the U.S. petrochemical industry (section 3.2) and its energy consumption and intensity (section 3.3).

\subsection{Process Description}

In the cracking process, hydrocarbon feedstocks are preheated in the convection section to $650^{\circ} \mathrm{C}$ (using fuel gas and waste heat), mixed with steam and cracked in the radiant section at a temperature of about $850^{\circ} \mathrm{C}$ (Worrell et al., 1994). Subsequently, the gas mixture is rapidly cooled to $400^{\circ} \mathrm{C}$ (or quenched) to stop the reaction, during which process high pressure steam is produced. Injection of water further decreases the temperature to about $40-50^{\circ} \mathrm{C}$ and a condensate, rich in aromatics, is formed. The liquid fraction is extracted, while the gaseous fraction is fed to a series of low temperature, high pressure distillation columns. The fractionation sequence varies from plant to plant (Zeppenfeld et al., 1993). Figure 3 shows a typical arrangement.

Feedstocks used in steam cracking are ethane, LPG, naphtha, gas oils (GOs) and sometimes coalderived feedstocks. Many of the installations used today can handle different (if not all) types of feedstock (Chemfacts, 1991). The choice for a particular feedstock, together with processing conditions (heat, pressure, steam dilution rate) will determine the yield of ethylene, propylene and other co-products in steam cracking. Table 7 shows how product yield varies with feedstock type (Chauvel and Lefevbre, 1989). 
Table 7. Influence of feedstock on steam cracker yield (weight \%) (Chauvel and Lefebvre, 1989)

\begin{tabular}{|l|c|c|c|c|c|c|}
\hline \multirow{2}{*}{ Product } & \multicolumn{6}{|c|}{ Feedstock } \\
\cline { 2 - 7 } & Ethane & Propane & Butane & Naphtha & $\begin{array}{c}\text { Atmospheric gas } \\
\text { oil }\end{array}$ & $\begin{array}{c}\text { Vacuum } \\
\text { gas oil }\end{array}$ \\
\hline $\begin{array}{l}\text { Hydrogen } \\
\text { (95\% purity) }\end{array}$ & 9 & 2 & 2 & 2 & 1 & 1 \\
\hline Methane & 6 & 28 & 22 & 17 & 11 & 9 \\
\hline Ethylene & 78 & 42 & 40 & 34 & 26 & 21 \\
\hline Propylene & 3 & 17 & 17 & 16 & 16 & 14 \\
\hline Butadiene & 2 & 3 & 4 & 5 & 5 & 5 \\
\hline $\begin{array}{l}\text { Pyrolysis gasoline } \\
\text { Of which: }\end{array}$ & 2 & 7 & 7 & 19 & 18 & 19 \\
- Benzene & 2 & 3 & 3 & 7 & 6 & 4 \\
\hline toluene & 0 & 1 & 1 & 3 & 3 & 3 \\
\hline
\end{tabular}

Note ${ }^{1}$ These values are obtained at high severity and with recycling of unconverted ethane/propane streams

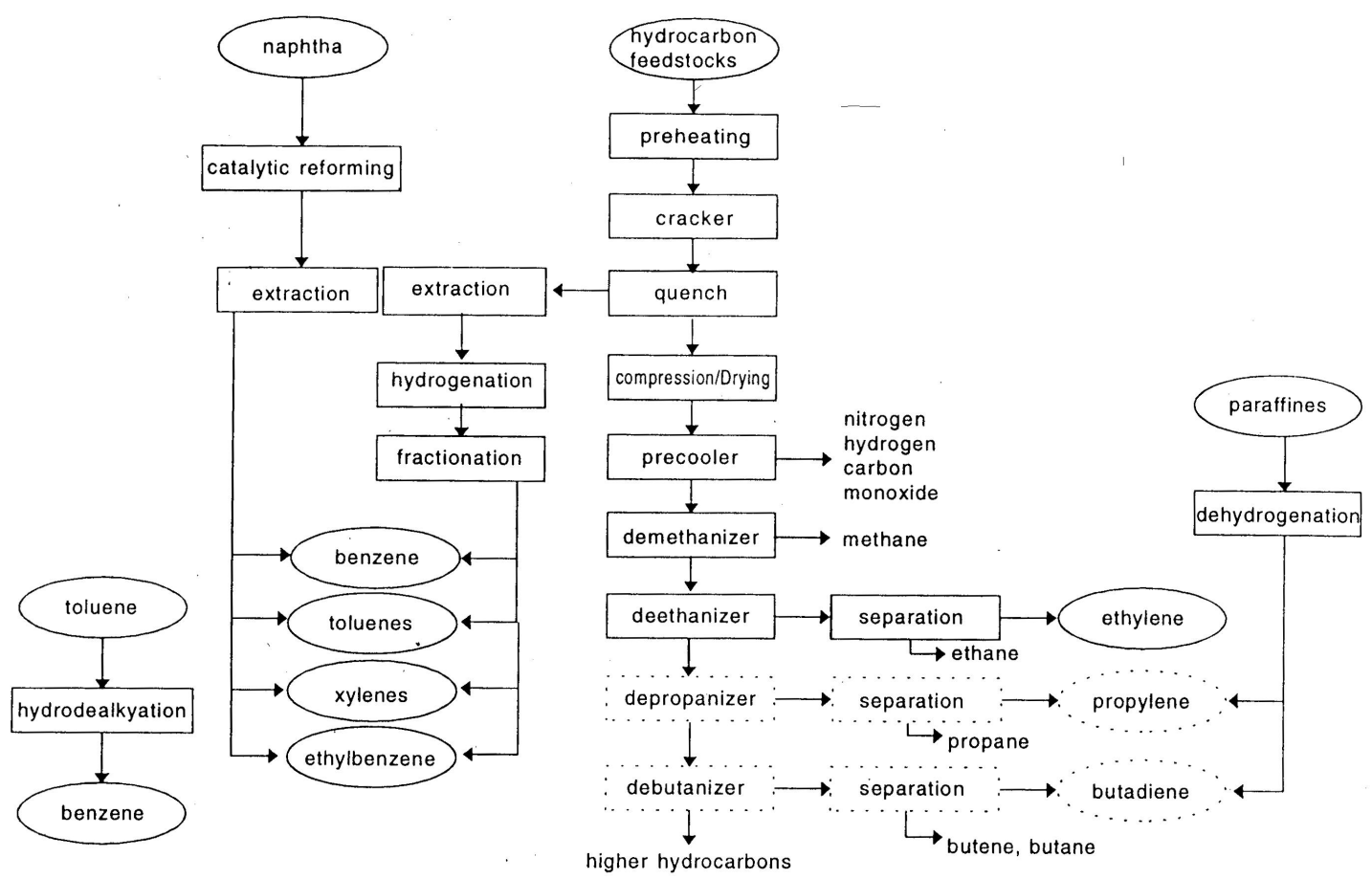

Figure 3. Process routes for the production of ethylene and its co-products (Phylipsen et al., 1998).

If ethane is used as feedstock, almost no propylene, butadiene and aromatics are formed as byproducts. Therefore, other processes are used for producing these chemicals in countries that predominantly use ethane cracking. In the U.S. propylene is also retrieved from refinery fractions (resulting from fluid catalytic cracking or hydro cracking). Another possibility is catalytic dehydrogenation of propane, but the share of this process is negligible at this moment. Aromatics (such as benzene, toluene and xylenes, or BTX) are usually produced by hydrogenation and desulphurisation of pyrolysis gasoline, after which the different components are separated by solvent/solvent extraction. Another route for BTX production is catalytic reforming of naphtha, followed by extraction of individual compounds out of the reformate. Furthermore benzene can be produced by hydro-de-alkylation of toluene. The different routes for petrochemicals production are shown in Figure 3. 


\subsection{The U.S. Petrochemical Industry}

The U.S. is currently the largest ethylene producer in the world, producing about 20 Million tonnes in recent years (1994-1996) (Chemical and Engineering News, 1997). Table 8 compares the U.S. ethylene capacity and feedstock mix with other major producers. The shares of feedstocks used in U.S. ethylene production in 1995 are listed in more detail in Table 9 (Chemfacts, 1991; O\&GJ, 1994, 1997, 1998). These tables show the relatively high share of ethane used for ethylene production in the US compared to the global average feedstock input (Appendix A provides a plant-by-plant overview of feedstock input). The difference is caused by the availability of abundant, cheap ethane as a by-product of natural gas and oil production.

Table 8. The US ethylene capacity and feedstock input compared to other major producers (all countries/regions with a capacity of over 1 Million tonne/year are shown (O\&GJ, 1998), unless otherwise noted)

\begin{tabular}{|l|c|c|}
\hline Country & $\begin{array}{c}\text { Share of world ethylene } \\
\text { capacity }\end{array}$ & Share of ethane in feedstock \\
\hline U.S. & $28 \%$ & $42 \%$ \\
Western Europe & $22 \%$ & $8 \%{ }^{1}$ \\
Japan & $8 \%$ & $0 \%{ }^{2}$ \\
FSU & $5 \%$ & \\
China (including Taiwan) & $5 \%$ & $0 \%{ }^{3}$ \\
South Korea & $5 \%$ & $76 \%{ }^{3}$ \\
Saudi Arabia & $4 \%$ & $72 \%{ }^{3}$ \\
Canada & $4 \%$ & $3 \%^{3}$ \\
Brazil & $3 \%$ & $100 \%{ }^{3}$ \\
Mexico & $2 \%$ & \\
India & $2 \%$ & $\mathbf{2 8 \%}$ \\
Others & $12 \%$ & \\
\hline World & $\mathbf{9 0 ~ M t}$ & \\
\hline
\end{tabular}

Notes: 1) in 1989 (Joosten, 1998); 2) 90\% naphtha, 10\% LPG in 1994 based on capacity (HP, 1995); 3) typical feedstock, based on 1996 plants (Rhodes, 1997); 4) includes all ethylene producers in Western Europe.

Table 9. Estimated feedstock input for the U.S. and total world ethylene production capacity in 1995 (as \% of ethylene capacity) (Chemfacts, 1991; O\&GJ, 1994, 1998; Rhodes, 1997)

\begin{tabular}{|l|c|c|c|c|c|}
\hline & Ethane & Propane/Butane & Naphtha & Gas oil & Others \\
\hline U.S. & $42 \%$ & $25 \%$ & $20 \%$ & $10 \%$ & $3 \%$ \\
World & $28 \%$ & $12 \%$ & $52 \%$ & $6 \%$ & $2 \%$ \\
\hline
\end{tabular}

Figure 4 shows historical production rates of ethylene and its co-products for the U.S. The average annual growth rate for ethylene production has been around 3\% since 1974. Propylene production increased 4\% per year (Chemical and Engineering News, 1997b). In recent years, global capacity for ethylene production has outgrown ethylene demand (O\&GJ, 1998; Chemical Market Reporter, 1998). In spite of already existing over-capacity, global ethylene capacity is expected to grow from 89 Million tonnes/year in 1997 to 103 Million tonnes/year in 2000. According to Chemical Markets Associates Inc. (a Houston-based consulting firm) ethylene demand in 2000 is expected to be about 90 Million tonnes/year (O\&GJ, 1998). Utilisation rates are expected to drop below $90 \%$, with ethylene margins decreasing $40-50 \%$ compared to the March 1998 levels (Chemical Market Reporter, 1998). The expected capacity growth in the U.S. of about 7 Million tonnes/year between 1998 and 2002 is second only to that in East Asia (Rhodes, 1997; O\&GJ, 1998). 


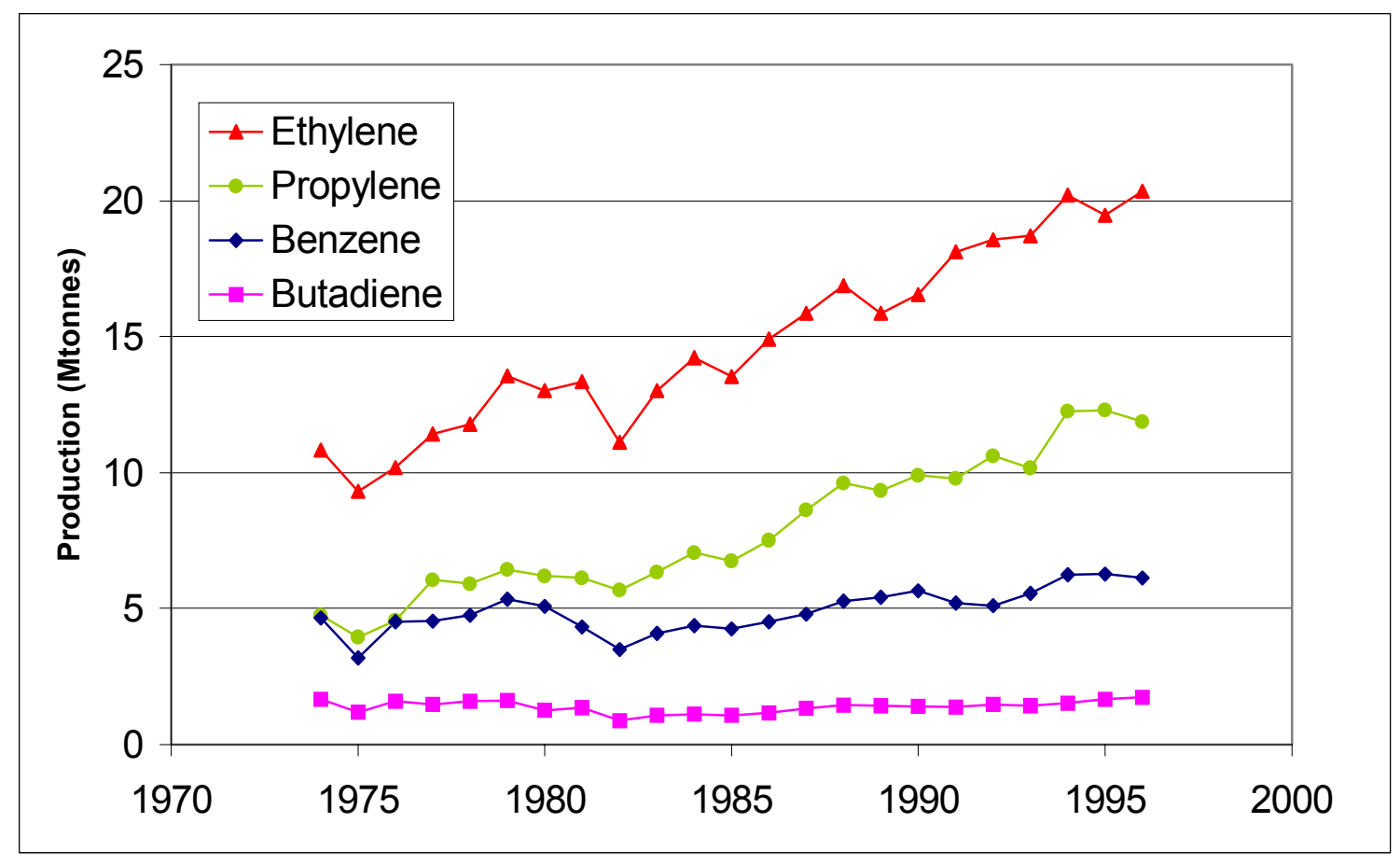

Figure 4. Historical production rates of major petrochemicals in the U.S. (Chemical and Engineering News, 1997)

Average plant capacity for the U.S. is about 600,000 tonnes ethylene per year (O\&GJ, 1998). A typical size for new U.S. plants is somewhat higher: 800-900,000 tonnes per year. Ethane-based plants generally have a higher capacity than liquid (naphtha/gas oil) crackers. Liquid crackers require a higher throughput of feedstock per unit of ethylene produced and get more easily contaminated. Larger plants are, generally, more efficient (Solomon, 1995).

\section{Age of technology}

Estimates of the average age and age distribution of ethylene production facilities vary. For example, according to Exxon Chemical Company Basic Chemicals Americas, as of $199875 \%$ of U.S. ethylene capacity is no older than 10 years (Chemical Market Reporter, 1998b). However, Los Alamos National Laboratory reports that $75 \%$ of current plants in the U.S. olefins industry are older than 20 years (LANL, 1996). Often plant sites and the basic design of a plant may be much older (dating back to 1962, see also Appendix A). It is very difficult to determine which part of the installations has been replaced since the time of construction. As might be expected newer plants are, generally, more efficient than older ones. The difference between plants built in the early seventies and the early nineties is on average 40\% (worldwide) (Solomon, 1995).

\section{Economics}

Manufacturing plants fed with ethane and propane can be constructed at much lower investment costs than naphtha crackers (Chemical Market Reporter, 1998b). For a 450,000 tonnes/year plant, investment costs vary from $\$ 430 /$ tonne ethylene for ethane crackers, $\$ 645 /$ tonne ethylene for naphtha crackers to $\$ 755 /$ tonne ethylene for gas oil crackers (1993-\$) (Gielen et al., 1996) ${ }^{3}$. For larger plants, investment costs (per tonne of ethylene) will be lower. Production costs vary from

${ }^{3}$ These estimates are based on Dutch production plants. However, according to (Gielen et al., 1996) investment costs are similar for U.S. Gulf Coast plants. 
\$295-430/tonne ethylene for ethane-based production (with the US on the high side of the range), about $\$ 755 /$ tonne ethylene for naphtha crackers to $\$ 940 /$ tonne ethylene for gas oil-based production (Gielen et al., 1996). The variation in production costs are caused by differences in e.g. investment costs, labor costs, feedstock and energy prices, ethylene yield (per unit of feedstock). Heavier feedstocks will result in by-products, generating additional revenues. Investment costs for flexible crackers (able to use different types of feedstock) are generally higher than dedicated crackers (designed for one particular feedstock). However, flexible crackers have the opportunity to choose a different (cheaper) type of feedstock if feedstock prices change Overall profitability of flexible crackers versus dedicated crackers depends on the price developments in different feedstocks and different products (ethylene versus propylene, butadiene and aromatics). In August 1998 cash margins for liquid-based crackers were higher than for ethane-based crackers (see Table 10) (Bonner \& Moore, 1998b).

Table 10. Cash margins for ethylene production for different feedstocks during August 1998 (Bonner \& Moore, 1998b).

\begin{tabular}{|l|c|}
\hline Feedstock & Cash margin (cents per kg) \\
\hline Ethane & $11.3-11.8$ \\
Propane & $13.3-14.0$ \\
Butane & $14.2-14.7$ \\
Naphtha & $14.2-14.9$ \\
Gas oil & $16.4-18.2$ \\
\hline
\end{tabular}

Note: Includes feedstock costs, co-product credits, variable costs, fixed costs and ethylene price

Purchased energy costs in North America in 1995 for the production of ethylene amounted to $\$ 2.11 / \mathrm{GJ}$ (\$2.23/MBtu), compared to \$3.90/GJ (\$4.11/MBtu) for Europe and $\$ 6.02 / \mathrm{GJ}$ (\$6.35/Mbtu) for Asia (Solomon, 1995). Between 1993 and 1995 energy costs in North America decreased 20\%, while in the same time energy costs in Europe rose by $3 \%$. Differences in energy prices are caused by the indigenous availability of energy resources, tax levels and competition of specific energy carriers for other applications (e.g. the application of fuels for space heating).

\section{Import/export}

U.S. ethylene net imports amounted to 230,000 tonnes in 1995 (equal to about $1 \%$ of U.S. production). Since then net imports have been decreasing to 5,000 tonnes in 1997 and as of 1998 the U.S. is expected to be a net exporter (Bonner \& Moore, 1998). Exports, however, are limited (less than $1 \%$ of total production). In general, transport costs will be too high to allow large-scale exports over long distances. As an example, the transportation costs for ethylene from the U.S. to India (excluding tariffs and import taxes) have been estimated at 1.5-2.5 times the U.S. production costs per tonne of ethylene (Chemistry \& Industry, 1996). This implies that the risk of U.S. companies relocating because of rising energy prices to supply the U.S. market from abroad is limited. In Europe and Asia energy prices are considerably higher. In the Middle East energy prices are lower, but capital costs are higher because of a lack of sufficient infrastructure and skilled labor (Gielen et al., 1996). The same is expected to be valid for Latin America. In 1993, the only countries/regions producing ethylene at significantly lower costs $(20-40 \%$ lower $)$ than the U.S. were Canada, Venezuela and (ethane-based capacity in) the Middle East (Hydrocarbon Processing, 1994). It seems likely that transportation costs (of both feedstock from the Gulf coast to the production site and of products to the U.S. market) and unstable political and economic climate (in the case of the Middle East and Latin America) will limit the relocation of U.S. production facilities. 


\subsection{Energy Use and Intensity in the U.S. Petrochemical Industry}

\section{Average Energy Efficiency}

Because of the emphasis on ethylene as the most important product from steam cracking in the past, the specific energy consumption per tonne of ethylene $\left(\mathrm{SEC}_{\mathrm{e}}\right)$ is a common measure of energy consumption for cracking. Modern plant values for $\mathrm{SEC}_{\mathrm{e}}$ are $14 \mathrm{GJ} /$ tonne of ethylene for ethane cracking (13 MBtu/ton, HHV) and 20-27 GJ/tonne of ethylene for naphtha/gas oil cracking (19-26 MBtu/ton, HHV) (Phylipsen et al., 1998a).

The cracker product mix is influenced by feedstocks and processing conditions (or severity which includes parameters such as temperature, pressure and furnace residence time). Using the specific energy consumption per tonne of ethylene $\left(\mathrm{SEC}_{\mathrm{e}}\right)$ as a measure of energy efficiency would mean that all energy consumption is allocated to ethylene, and none to the other products. This means that using another feedstock or severity will affect the $\mathrm{SEC}_{\mathrm{e}}$, even if total energy consumption does not change. In order to be able to compare different processes and feedstocks (with different yields for the various products) another allocation has to be used. In order to exclude effects from changing product yields, energy consumption should be allocated over all products formed in a particular process (on a mass basis).

Solomon Associates Ltd., a company performing energy efficiency analyses and comparisons for refineries and petrochemical plants world-wide, has developed an extensive network for this type of analysis. Participating companies provide Solomon with very detailed data on production, throughput, energy consumption, installed technology. In return, Solomon offers companies a comparison of their own plant's performance with that of all the other participating plants. Plant performance is measured by comparing the plant's actual energy consumption to a reference level of energy consumption, based on the most efficient technology available, using the plant's own configuration, including feedstock input, severity, and product mix. Specific energy consumption is defined as the net energy consumption (lower heating value, LHV 4 ) per unit of high value chemicals (including hydrogen, ethylene, propylene, a mixed butenes fraction and a BTX fraction ${ }^{2}$. The energy efficiency is presented as the ratio of the actual SEC to the reference SEC; the energy efficiency index, in which 100 equals the efficiency of the state-of-the-art reference system.

According to Solomon the energy efficiency index (EEI) of the naphtha/gas oil-based crackers in the U.S. is 163 (in 1995). These crackers, located in Texas and Louisiana, account for about 40\% of ethylene production (10Mt) (Solomon, 1998). The EEI of all cracking activities in North America (including the U.S., Canada and Mexico) equals 175 (Solomon, 1995). The U.S. accounts for $85 \%$ of the capacity in North America (O\&GJ, 1998).

\footnotetext{
${ }^{4}$ Lower heating value (LHV) and higher heating value (HHV) are both measures of energy consumption. Higher heating values measure the heat that is freed by the combustion of fuels in case the chemically formed water is condensed. Lower heating value measure the heat of combustion in case the water formed remains gaseous. Although the energy difference between HHV and LHV may not always be technically recoverable, from the perspective of energy efficiency analysis HHV is considered preferable, because it is a better measure of the energy inefficiency of processes. In the US HHV is commonly used in energy reporting, in many other countries LHV is more common. Organisations such as Eurostat, the IEA and the UN also use LHV (Phylipsen et al., 1998).

${ }^{5}$ Measured in tonnes of benzene
} 
In the 1995 analysis, ethane/propane crackers were less efficient than naphtha/gas oil crackers The global average EEI of ethane crackers was 200, while including all propane crackers improves the EEI to 180 (Solomon, 1995). Assuming 40\% of U.S. ethylene production had an EEI of 163 and $60 \%$ of ethylene production had an EEI of 180 , leads to an estimated overall EEI for the U.S. of 173. This matches closely with the EEI of 175 reported for North America. Considering the US product mix (an average ethylene yield of 51-53\%), our best estimate of the specific energy consumption would be about $13 \mathrm{GJ} /$ tonne (LHV) of total product (or 13.3 MBtu/ton, HHV). For the U.S. product mix the SEC per tonne of high value chemicals amounts to about $20 \mathrm{GJ}$ (LHV)/tonne, while SEC per tonne of ethylene amounts to $26 \mathrm{GJ}$ (LHV)/tonne of ethylene (HHVs are $19.1 \mathrm{MBtu} / \mathrm{ton}$ high value chemicals and $24.8 \mathrm{MBtu} / \mathrm{ton}$ ethylene respectively) (Phylipsen et al., 1998b).

Figure 5 depicts the estimated average U.S. performance compared to all the plants in the Solomon survey (Solomon, 1995). Table 11 shows the EEI for several regions with the U.S. included in 'North America'. The U.S. accounts for about $85 \%$ of the ethylene capacity in North America. The Solomon survey covers on average about $70 \%$ of the plants worldwide, with somewhat higher coverage in the U.S. and Europe, and somewhat lower in Asia.

\section{ENERGY EFFICIENCY INDEX}

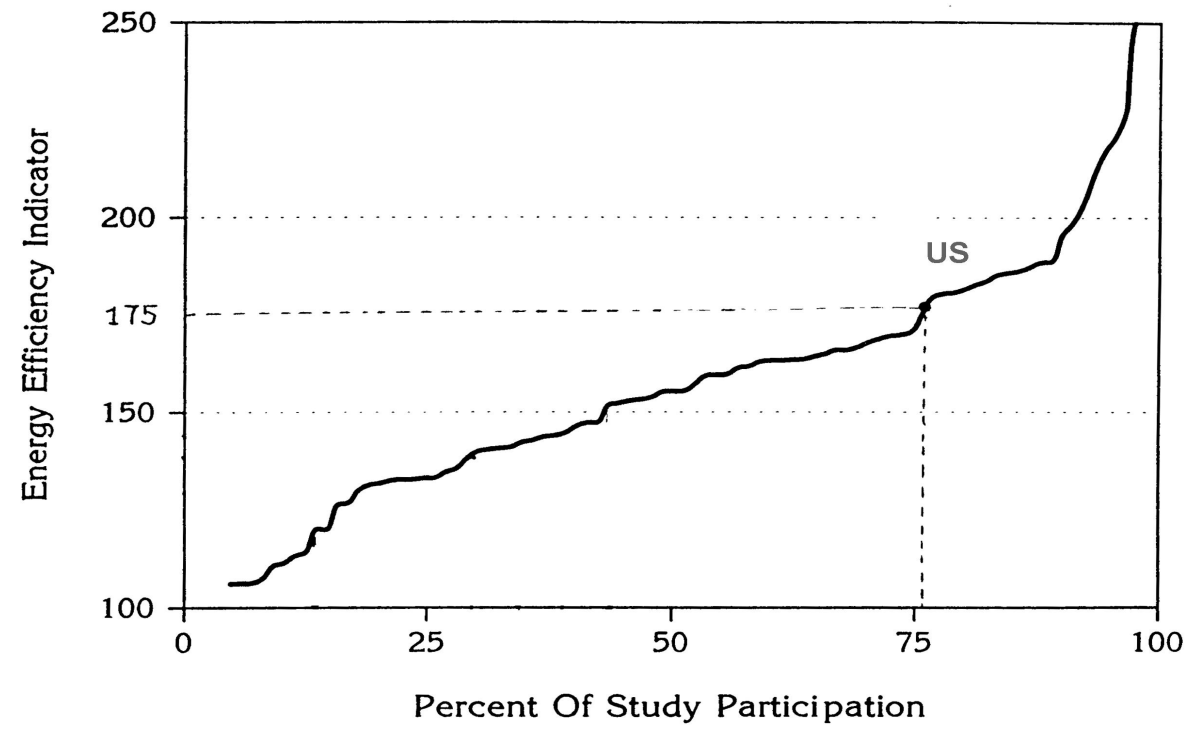

Figure 5. The relative performance of the US ethylene plants.

\footnotetext{
${ }^{6}$ There is no specific reason why ethane/propane crackers are less efficient than liquid crackers. The observed difference may be caused by the fact that the highest share of liquid crackers are generally located in more efficient countries (such as Japan, South Korea, Germany, The Netherlands). Factors that are likely to play a role are the higher feedstock price for naphtha/gas oil (per tonne of ethylene produced) and the generally higher energy prices in these countries.
} 
Table 11. The energy efficiency index for several regions according to the Solomon survey (stateof-the-art-technology = 100) Source: Solomon (1995).

\begin{tabular}{|l|c|}
\hline Region & Energy Efficiency Index \\
\hline North America & 175 \\
Europe & 151 \\
Asia & 126 \\
Total study & 164 \\
\hline
\end{tabular}

With an ethylene production of about 20Mt total U.S. energy consumption for the production of ethylene and its co-products is estimated to be about 520 PJ excluding feedstocks (LHV), and 2225 PJ including feedstocks (LHV) (0.53 Quads excluding, and 2.28 Quads including feedstocks in $\mathrm{HHV}$, respectively). Assuming a predominant use of petroleum products as energy source, carbon emissions resulting from the production of ethylene and its co-products would amount to $10 \mathrm{Mt} \mathrm{C}$ (excluding feedstocks).

\section{Energy consumption by process step}

Individual process steps in the production process of ethylene and its co-products are shown in Figure 3. In general, fuels are used to fire the cracking furnace and to generate steam. High pressure steam is used to drive compressors and pumps, medium pressure steam for dilution steam generation and low pressure steam for direct process heating (Di Cintio et al., 1993). A further breakdown of energy consumption in ethane cracking, the predominant feedstock in the U.S., is shown in Table 12 (derived from Brown et al., 1985).

Table 12. Detailed breakdown of energy consumption in ethane cracking (derived from Brown et al., 1985). Specific energy consumption is expressed per tonne of ethylene. Feedstock energy is excluded.

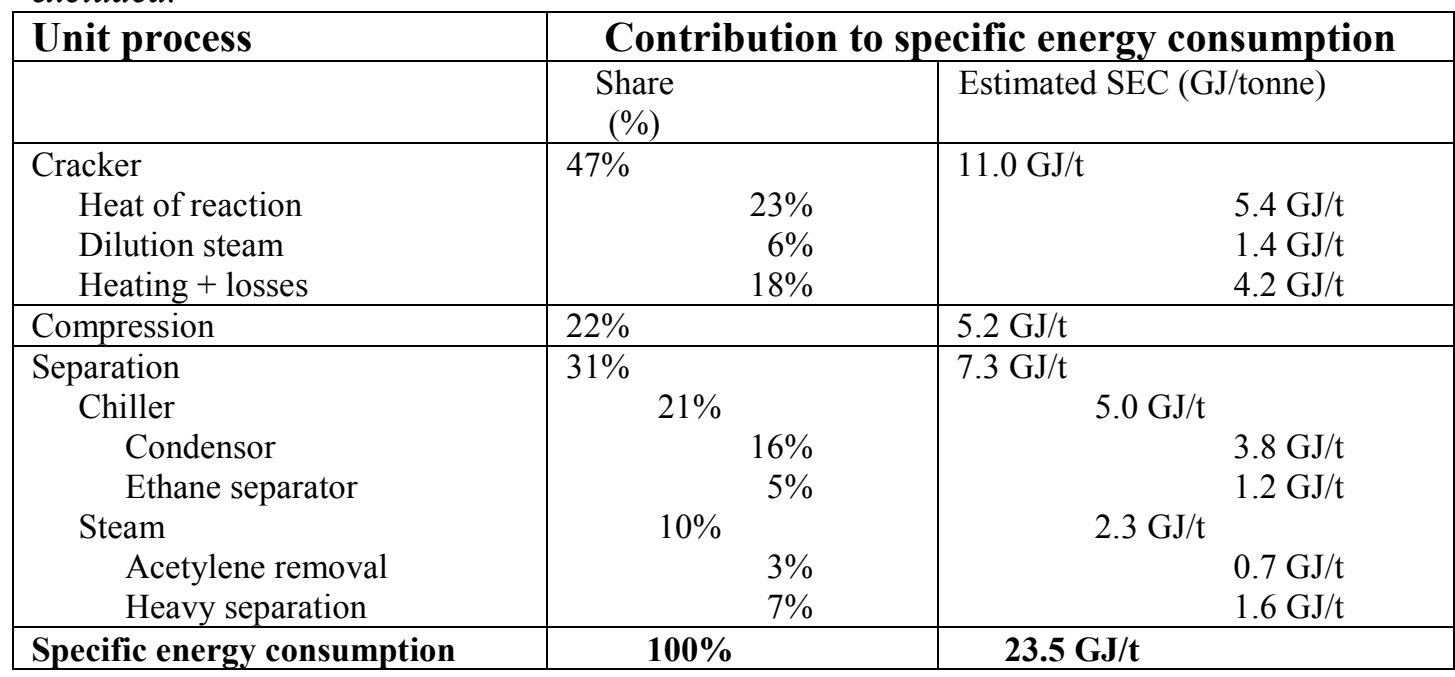

The breakdown of energy consumption in unit processes will vary with feedstock. Because of the lower ultimate ethylene yield per tonne of feed with heavier feeds, higher feed volumes are required to produce the same amount of ethylene than with ethane. This will result in higher compression and separation energy requirements for naphtha and gas oils compared to ethane. Ethane, however, has a lower initial conversion rate. As a result, recycle streams are larger,

7 In the calculation we use an emission factor of $20 \mathrm{~kg} \mathrm{C} / \mathrm{GJ}$ 
requiring more heating, compression, pumping and separation. These effects will partly outweigh each other. Table 13 shows how energy consumption varies with feedstock (Stratton, 1983).

Table 13. Breakdown of primary specific energy consumption (SEC) for ethylene production for different feedstocks. Feedstock energy is excluded. Source: Stratton (1983).

\begin{tabular}{|l|c|c|c|c|c|c|c|c|}
\hline \multirow{2}{*}{} & \multicolumn{7}{|c|}{ Feedstock } \\
\cline { 2 - 9 } & \multicolumn{2}{|c|}{ Ethan } & \multicolumn{2}{c|}{ Naphtha } & \multicolumn{2}{c|}{ Gas Oil } & \multicolumn{2}{c|}{ U.S. Mix } \\
\cline { 2 - 9 } & GJ/t & $\%$ & GJ/t & $\%$ & GJ/t & $\%$ & GJ/t & $\%$ \\
\hline $\begin{array}{l}\text { Heat of } \\
\text { Reaction }\end{array}$ & 4.8 & $21 \%$ & 6.2 & $20 \%$ & 12.4 & $33 \%$ & 6.0 & $23 \%$ \\
\hline Compression & 3.5 & $16 \%$ & 3.5 & $13 \%$ & 4.1 & $11 \%$ & 3.7 & $14 \%$ \\
\hline $\begin{array}{l}\text { Heating and } \\
\text { Separation } \\
\text { Losses }\end{array}$ & 14.2 & $63 \%$ & 17.7 & $66 \%$ & 20.6 & $55 \%$ & 16.8 & $63 \%$ \\
\hline SEC & $\mathbf{1 9 . 4}$ & & $\mathbf{2 6 . 2}$ & & $\mathbf{3 1 . 9}$ & & $\mathbf{2 6 . 5}$ & \\
\hline
\end{tabular}

Note: The U.S. mix is assumed to be $60 \%$ ethane, $30 \%$ naphtha and $10 \%$ gas oil.

Although the energy consumption data underlying the shares listed in Table 13 are relatively old, the efficiency level is comparable to the current U.S. situation. Calculating the weighted average, based on the U.S. feedstock mix and the total specific energy consumption figures listed in Table 13 , leads to a SEC of $26.5 \mathrm{GJ} /$ tonne ethylene, compared to our estimate of $26 \mathrm{GJ} /$ tonne ethylene for the U.S. The ethane cracker described in Table 12 is slightly less efficient than the one included in Table 13.

Table 13 shows only a limited breakdown In order to estimate energy savings potentials by individual measures a more detailed breakdown is needed, especially for the category of 'heating, separation and losses'. For ethane we use the subdivision listed in Table 12. For other feedstocks a more detailed breakdown of energy consumption is given in Table 14, showing a naphtha cracker and a naphtha/ethane-propane-butane cracker (Di Cintio et al, 1993).

Table 14. Detailed breakdown of energy consumption for a naphtha cracker and a flexible cracker. Source: Di Cintio et al (1992).

\begin{tabular}{|l|r|r|r|r|}
\hline \multirow{2}{*}{} & \multicolumn{2}{|c|}{ Naphtha Cracker } & \multicolumn{2}{c|}{ Flexible Cracker } \\
\cline { 2 - 5 } & SEC (GJ/tonne) & Share (\%) & SEC (GJ/tonne) & Share (\%) \\
\hline Feedstock Heating & 20.7 & $65 \%$ & 13.1 & $55 \%$ \\
Compression & 4.8 & $15 \%$ & 3.6 & $15 \%$ \\
Separation & 6.3 & $20 \%$ & 7.2 & $30 \%$ \\
\hline Total & $\mathbf{3 1 . 5}$ & & $\mathbf{2 3 . 9}$ & \\
\hline
\end{tabular}

Notes: The EEI of a naphtha cracker is about 150 (Phylipsen et al., 1998b) and of a high efficiency cracker, the EEI is approximately 120 . In this calculation we assume a feedstock-mix of $70 \%$ naphtha, and $30 \%$ ethane/propane/butane (Di Cintio et al., 1993).

According to Tables 12, 13 and 14 the energy consumption for separation varies between 6.3-7.3 GJ/tonne ethylene. Based on the U.S. feedstock mix and efficiency, we estimate separation energy consumption for the U.S. to be $7 \mathrm{GJ} /$ tonne ethylene. The compression energy ranges from 3.5-5.2 GJ/tonne ethylene. Taking into account feedstock and efficiency, energy consumption for compression in the U.S. is estimated to be $4 \mathrm{GJ} /$ tonne ethylene. With a total specific energy consumption of $26 \mathrm{GJ} /$ tonne ethylene, cracker/feedstock heating energy consumption results in 15 GJ/tonne. Based on dilution steam rates listed by Di Cintio et al (1993) for various feedstocks and the U.S. feedstock mix, energy consumption for dilution steam can be estimated at $2 \mathrm{GJ} /$ tonne 
ethylene. Table 15 shows the results for the detailed breakdown of energy consumption in U.S. crackers.

Table 15. Estimated energy consumption by process step in U.S. ethylene production.

\begin{tabular}{|l|c|c|}
\hline \multirow{2}{*}{} & \multicolumn{2}{|c|}{ U.S. Feedstock Mix } \\
\cline { 2 - 3 } & SEC (GJ/tonne ethylene) & Share (\%) \\
\hline Cracker & 15.0 & $58 \%$ \\
Reaction Heat & 7.0 & $26 \%$ \\
Dilution Steam & 2.0 & $8 \%$ \\
Heating and Losses & 8.0 & $31 \%$ \\
Compression & 4.0 & $15 \%$ \\
Separation & 7.0 & $27 \%$ \\
\hline Total & $\mathbf{2 6 . 0}$ & \\
\hline
\end{tabular}




\section{The Ammonia and Nitrogenous Fertilizer Industry}

This chapter reflects an in-depth analysis of the ammonia and nitrogenous fertilizer industry. The nitrogen fertilizer industry is a large energy consumer, with an estimated worldwide annual production capacity of over 100 Mtonnes $\mathrm{N}$ and estimated energy consumption equal to $1 \%$ of global primary energy use. The production of ammonia is the most energy intensive production step in the manufacture of fertilizers and other nitrogen containing products. In the U.S. ammonia is one of the major chemicals produced, with an estimated production of 16.3 Mtonnes (18.0 Million short tons) (CMA,1996). In the U.S. about $80 \%$ of the ammonia is used for fertilizer production, the remainder for a variety of products, mainly explosives and plastics. The most important fertilizers produced in the U.S. are ammonium nitrate (AN), nitric acid (NA), urea, compound fertilizers, and liquid ammonia. Ammonium sulfate (AS) is most commonly produced as a co-product of nylon manufacturing.

The world fertilizer market grows slowly, due to growth especially in developing countries. The world market price of ammonia has been depressed since the late 1980's due to cheap exports from producers in Central and eastern Europe and the former Soviet Union, limiting expansion in the Western World (especially Western-Europe). The U.S. fertilizer market is still slowly growing (IFA,1998), and ammonia prices have been high since 1994 (USGS,1998). The U.S. is a net importer of ammonia, and of some fertilizer types, e.g. urea. The main imports are from countries with cheap natural gas resources, i.e. Trinidad and Tobago, and Canada. Some U.S. firms operate or construct plants abroad, e.g. in Trinidad (e.g. Mississippi Chemical).

In this chapter we first discuss the major process used to make ammonia and nitrogenous fertilizers (section 4.1), followed by a discussion of the U.S. ammonia industry (section 4.2) and energy consumption and intensity (section 4.3).

\subsection{Process Description}

Ammonia is produced by the reaction of nitrogen and hydrogen, the so-called Haber-Bosch process. The main hydrogen production processes used in the U.S. are steam reforming of natural gas and partial oxidation of oil residues. Hydrogen is produced by reforming the hydrocarbon feedstock, producing synthesis gas, contining a mixture of carbon monoxide and hydrogen. The carbon monoxide is then reacted with steam in the water-gas-shift reaction to produce carbon dioxide and hydrogen. The carbon dioxide is removed from the main gas stream. The carbon dioxide is recovered for urea production or exported as a co-product, or vented. The hydrogen then reacts with nitrogen in the final synthesis loop, to form ammonia. The anhydrous ammonia is sold as product, or used to produce a variety of fertilizers, or other products. For a detailed description of the ammonia production process, see Worrell and Blok (1994). Ammonia production typically requires between 28 and $40 \mathrm{GJ} /$ tonne $(\mathrm{LHV})^{8}$ of ammonia, including feedstocks 9 U.S. energy consumption for ammonia manufacture is roughly estimated at 790 PJ (HHV) (Lipinsky and Ingham,1994). The specific energy consumption (SEC) of modern partial oxidation units is $30 \mathrm{GJ} /$ tonne (Lurgi,1987),

\footnotetext{
${ }^{8}$ The heating value of a fuel can be expressed in lower (or net) heating value (LHV) and higher (or gross) heating value (HHV). The difference is the condensation heat of the water vapor of the combustion process, which is included in the HHV. LHV is commonly used in international statistics and in Europe, while HHV is used in the U.S. and Canada. Natural gas in the U.S. has a set HHV of $38.4 \mathrm{MJ} / \mathrm{Nm} 3$ or 1,030 Btu/scf. The LHV is approximately $11 \%$ lower.

${ }^{9}$ Feedstock consumption is estimated to be 19 to $22 \mathrm{GJ} /$ tonne (LHV) ammonia. Note that although energy use is earmarked as feedstock, the carbon may be emitted to the atmosphere if it is not used for urea manufacture, or recovered for other purposes (e.g. soft drink manufacture). Total energy consumption is equivalent to 24-34 MBtu/short ton ammonia.
} 
and upto $30 \%$ higher for older units (Nitrex,1989). The SEC of modern natural gas steam reforming is 27 to $28 \mathrm{GJ} /$ tonne (Appl,1994).

Although, ammonia is used directly as a fertilizer in the U.S., most of the ammonia is converted to other compounds to be used as fertilizer. We give a short description of the main processes for fertilizer production.

Urea is produced in two steps by the reaction of $\mathrm{NH}_{3}$ and $\mathrm{CO}_{2}$. The $\mathrm{CO}_{2}$ is produced in the $\mathrm{NH}_{3}$ synthesis. In the first step, carbamate $\left(\mathrm{NH}_{2} \mathrm{CO}_{2} \mathrm{NH}_{4}\right)$ is synthesized. Feedstock is provided in an $\mathrm{NH}_{3} / \mathrm{CO}_{2}$ ratio varying from 2.5 to 3.5 to achieve a high conversion rate. In the second step, the carbamate is dehydrated to urea. The reaction is not complete. Therefore $\mathrm{NH}_{3}$ and $\mathrm{CO}_{2}$ are both stripped from the urea solution and recycled. Commercial processes differ in the dehydration step. The main processes are solution recycle $\left(\mathrm{NH}_{3}\right.$ and $\mathrm{CO}_{2}$ are recycled to the synthesis reactor as an aqueous solution) and stripping process (the non-reacted carbamate is removed by partial pressure reduction, using one of the reactants). Several techniques are used to dry the urea solution. Normally the solution is treated in a prilling tower, to produce granulate. In Europe the urea plants consume between 3.2 and $4.6 \mathrm{GJ} /$ tonne of primary energy (Worrell and Blok,1994). The $\mathrm{CO}_{2}$ is extracted from the $\mathrm{NH}_{3}$-process, so no energy is consumed. However in some $\mathrm{NH}_{3}$ processes there is a $\mathrm{CO}_{2}$ deficiency (depending on the production volumes of $\mathrm{NH}_{3}$ and urea) which is met by extra $\mathrm{CO}_{2}$ production (which consumes energy and emits carbon dioxide) in a separate plant.

Nitric Acid (NA) is used mainly for the production of ammonium nitrate $\left(\mathrm{NH}_{4} \mathrm{NO}_{3}\right) . \mathrm{HNO}_{3}$ is also used to produce non-fertilizer products. $\mathrm{NH}_{3}$ is burned over catalysts to produce nitrous oxides. The $\mathrm{NO}_{\mathrm{x}}$ are passed to an absorber column to produce $\mathrm{HNO}_{3}$ (reaction with water). The total process is highly exothermic, so waste heat boilers are installed to generate superheated high pressure steam. Two main types of processes can be identified: mono-pressure (oxidation and absorption pressures are the same) and dual-pressure (absorption pressure is higher than oxidation pressure). For both types a large number of different processes (with different operating pressures) have been developed. New designs have been developed which have a lower steam consumption (due to the incorporation of expansion turbines) or which have increased heat recovery.

Ammonium nitrate (AN) is produced by the neutralization of $\mathrm{HNO}_{3}$ with $\mathrm{NH}_{3}$, in an exothermic reaction. The released heat can be used in the process internally (to evaporate the water of the $\mathrm{HNO}_{3}$ solution, or to preheat the $\mathrm{HNO}_{3}$, or evaporate the liquid $\mathrm{NH}_{3}$ ) and can produce steam, which can be exported. Whereas older plants work at atmospheric pressures (which require the import of steam), most modern processes work at elevated pressures (and export low pressure steam).

Ammonium sulfate (AS) is produced as a byproduct of nylon 6,6 manufacture. In the synthesis of caprolactam ammonia is added to control the reaction. As much as three to five times as much ammonium sulfate may be produced than caprolactam (Lipinsky and Ingham,1994). After separation of the ammonium sulfate solution, the water is evaporated to produce a marketable product.

\subsection{Characterization of the U.S. Ammonia Industry}

In the U.S. ammonia is produced in 41 plants (1996) which predominantly use natural gas as a feedstock, as can be seen from energy statistics (EIA,1997). Natural gas is the favorable feedstock for ammonia, as it has the highest hydrogen to carbon ratio, leading to reduced energy consumption, and carbon dioxide emissions. Natural gas based plants also have lower capital costs, although ammonia manufacture remains capital intensive. The capital costs for a new greenfield plant are estimated at roughly $\$ 300$ per tonne annual capacity (Worrell and Blok,1994). Although currently available data makes it impossible to calculate the average age of 
ammonia production facilities in the U.S, the original production capacity in the U.S. seems relatively old. It is important to note that many plants have undergone various reconstructions and expansions, changing the process lay-out and improving performance, compared to the original plant. Concentration of production in medium to large-scale plants has taken place in the last decade. Future capacity or expansion will probably take place only in areas with low natural gas prices, e.g. Texas, Louisiana, and Oklahoma. Almost $60 \%$ of U.S. ammonia capacity is located in these states (USGS,1998).

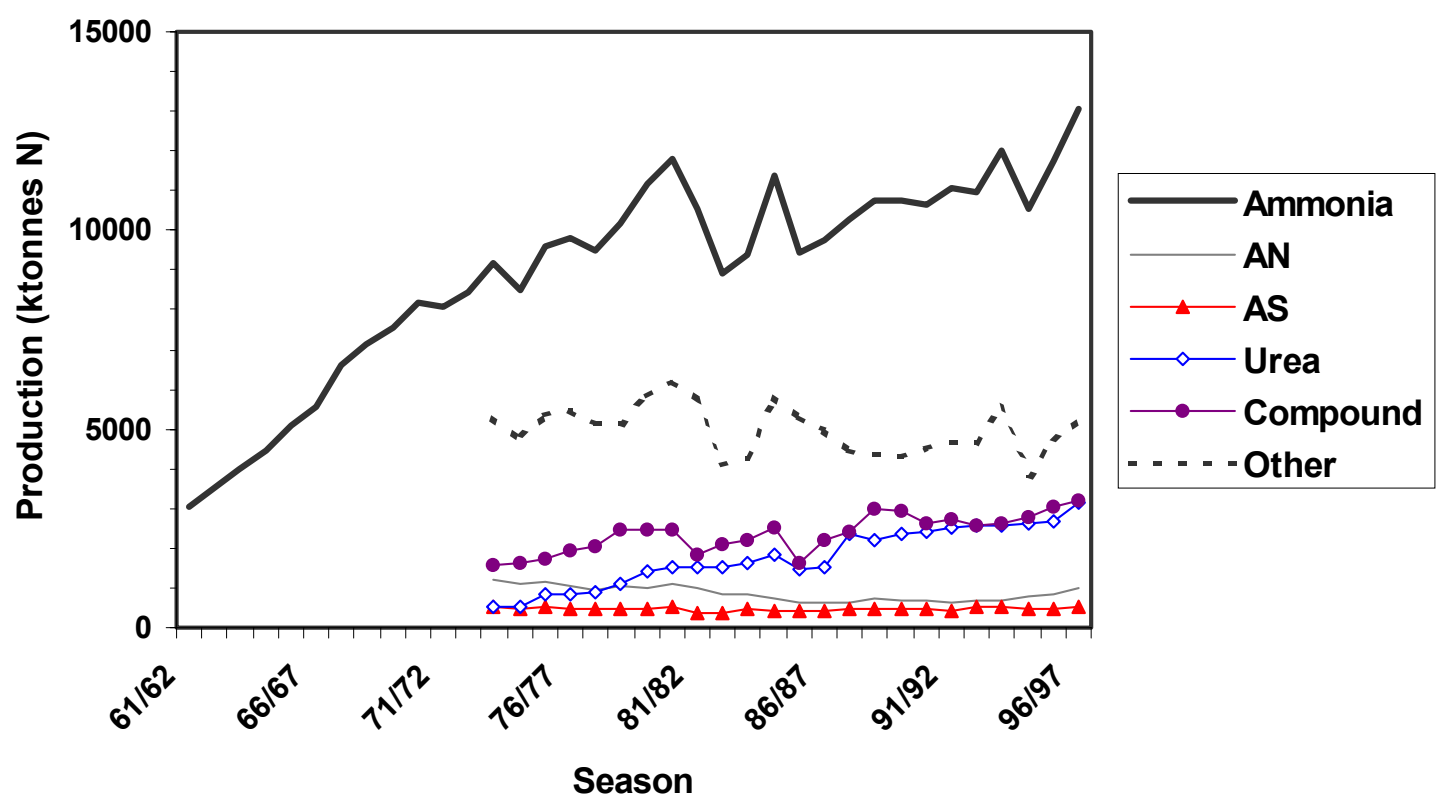

Figure 6. Historic U.S. production of ammonia, and some major fertilizers, expressed in 1000 metric tonnes of Nitrogen. The data are given for the agricultural season, as provided by the International Fertilizer Association (IFA,1998). Data of the Chemical Manufacturers Association (CMA,1996) are given by calendar year, and vary slightly from the IFA data.

\subsection{Energy Use and Intensity in the U.S. Ammonia Industry}

\section{Methodology}

The U.S. Manufacturing Energy Consumption Survey reports only the energy consumption for the nitrogenous fertilizer industry as whole, which includes not only the manufacture of ammonia, but also the production of urea, nitric acid, ammonium nitrate, and compound fertilizers. For part of the fertilizers it also contains the granulation of the fertilizers. The MECS does not report on the ammonia process itself. Hence, we have to estimate the energy intensity of ammonia making in the U.S. based on the total energy consumption in the sector, as well as on other sources, e.g. an annual survey of North-American ammonia producers by The Fertilizer Institute.

\section{Energy Use and Carbon Dioxide Emissions}

Energy consumption for ammonia and fertilizer production consists of consumption as energy for fueling the chemical process, as well as the energy used as feedstock. With respect to consumption for fueling the chemical processes, the U.S. Manufacturing Energy Consumption Survey estimated the consumption for the production of nitrogenous fertilizers (SIC 2873) to be 
$288 \mathrm{PJ}$ in fuels and 13.7 PJ electricity in 1994. Consumption of energy sources for feedstock is estimated at 368 PJ (EIA,1997). The specific feedstock consumption is estimated to be 22.6 $\mathrm{GJ} /$ tonne ammonia (HHV).

Carbon emissions can be estimated on the basis of total fuel consumption of the sector, accounting for the carbon dioxide that is used as feedstock in urea manufacture, $\frac{10}{2}$ and carbon dioxide recovered for other purposes. Urea production in 1994 is estimated at 8,067,000 tons (CMA,1996). On a molecular basis, $20 \%$ of the urea is carbon. The amount of carbon exported in urea is estimated at $1.46 \mathrm{MtC}{ }^{11}$ There are no data available on the amount of carbon dioxide recovered for other purposes in the U.S. ammonia industry. The total carbon emission in the U.S. (1994) is estimated to be minimal $9.07 \mathrm{MtC}{ }^{12}$ This is relatively low due to the high use of natural gas as the main feedstock and energy carrier ( $99 \%$ of fuels used).

\section{Non-CO $\mathrm{O}_{2}$ Greenhouse Gas Emissions}

The production of nitric acid is one of the industrial emission sources of nitrous oxide $\left(\mathrm{N}_{2} \mathrm{O}\right)$, besides the production of adipic acid (for Nylon 6,6). In the combustion of ammonia to produce nitric acid, some nitrous oxide may be formed as an accidental co-product. Off-gas measurements at DuPont showed a wide range in emissions, varying from 2 to $9 \mathrm{~g} \mathrm{~N}_{2} \mathrm{O} / \mathrm{kg} \mathrm{HNO}_{3}$ (IPCC, 1995). It is not known if the DuPont emission factors are representative for all processes used, or for the whole industry. The total emission of the U.S. fertilizer industry is estimated at 16-72 $\mathrm{Gg} \mathrm{N}_{2} \mathrm{O}$, equivalent to 1.4-6.1 Mt C (using a GWP of 310 for a 100 year time period (IPCC,1996)). US DOE estimates the 1994 nitrous oxide emission from nitric acid production at 47 ktonnes (EIA,1996), equivalent to 3.9 Mtonne C. At high concentrations (as with adipic acid production) the $\mathrm{N}_{2} \mathrm{O}$ emissions can be reduced by oxidation in a flame. It is not clear if this technology can also be used in the production of nitric acid. However, the wide range shows that good process control may influence the $\mathrm{N}_{2} \mathrm{O}$ emission. Future emission controls may be based on catalytic processes, but no technologies are commercially available yet.

\section{Energy Intensity and Carbon Dioxide Emissions}

U.S. energy statistics do not give direct information on the energy consumption for ammonia manufacture. As $80-90 \%$ of the primary energy in SIC 2873 is consumed in ammonia manufacture, the total consumption gives some rough information on the energy consumption (see above). According to a survey of the Fertilizer Institute among $77 \%$ of North American ammonia producers (incl. Canada) the energy intensity ammonia making is estimated at 39.3 $\mathrm{GJ} /$ tonne (HHV) of natural gas and $140 \mathrm{kWh}$ per tonne of ammonia (Vroomen, 1998). This is equivalent to a primary energy consumption of $40.9 \mathrm{GJ} /$ tonne (HHV) or $37.1 \mathrm{GJ} /$ tonne (LHV)). ${ }^{14}$

\footnotetext{
${ }^{10}$ Carbon dioxide is actually released to the atmosphere as soon as the urea is applied.

${ }^{11}$ This assumes that all carbon dioxide is recovered from ammonia manufacture, and that no extra carbon dioxide is produced for urea manufacture. However, back-up carbon dioxide generators are often available to meet peak $\mathrm{CO}_{2}$ demands. In that case, the actual $\mathrm{CO}_{2}$ will be higher than the figure mentioned above.

${ }^{12}$ The following emission factors are used for the carbon calculation: coal: $27.0 \mathrm{~kg} / \mathrm{GJ}$; natural gas: 15.3 $\mathrm{kg} / \mathrm{GJ}$, and for electricity: $50.5 \mathrm{~kg} / \mathrm{GJe}(\mathrm{EIA}, 1996)$.

${ }^{13}$ Note that the industrial emissions of nitrous oxide are relatively small compared to that of other sources, i.e. mobile sources. Also note that the application of fertilizers may lead to the emission of nitrous oxides, depending on the application method, soil type, groundwater level and fertilizer type.

${ }^{14}$ Lipinsky and Ingham (1994) estimated the 1992 total energy consumption for ammonia manufacture at 42.2 Mbtu/ton ammonia (16.1 Mbtu/ton for energy and 26.1 Mbtu/ton for feedstock). This is equivalent to $49.1 \mathrm{GJ} /$ tonne (HHV). This seems to be too high, compared to the information from the industry's survey, and to intensities in other countries (Worrell et al.,1994b).
} 
An analysis of energy intensities of ammonia manufacture in Europe showed that 1989 energy consumption varied between $28 \mathrm{GJ} /$ tonne (Spain, LHV) and $40 \mathrm{GJ} /$ tonne (Belgium, LHV), while the average $1989 \mathrm{SEC}$ in the European Union is estimated at $35.5 \mathrm{GJ} /$ tonne (LHV) (Worrell et al.,1994b).

The theoretical minimum energy consumption for ammonia manufacture through steam reforming is approximately $21.6 \mathrm{GJ} /$ tonne ammonia (HHV). This illustrates the maximum potential for efficiency improvement, which is, however, not practically achievable, not even on the long term.

\section{Energy Balance for Ammonia Making}

For a detailed analysis of the impact of energy efficient practices and technologies on energy intensity and carbon dioxide emissions we generated a detailed energy balance of the ammonia manufacturing process. We constructed a detailed balance on the basis of the specific energy consumption of ammonia plants in the U.S. (based on the Fertilizer Institute Survey (Vroomen,1998)), the feedstock consumption given by MECS (EIA,1997), and energy balances given by Nielsen (1995) and Brown et al. (1985). An recent analysis provides an energy and exergy balance for an energy efficient process (Nielsen, 1995) while the study by Brown et al. (1985) reports on older plant, being more energy intensive than the current U.S. situation. We combined the insights of both analyses to estimate an average energy balance for the U.S. In Table 16 we give the energy balance broken down to the major process steps and unit-operations.

Table 16. Estimated energy balance for U.S. ammonia manufacturing (1996). Boiler efficiency is assumed to be $78 \%(H H V)$ or $86 \%$ (LHV). Power generation efficiency is assumed to be $33 \%$.

\begin{tabular}{|c|c|c|c|c|c|c|c|c|c|c|}
\hline \multirow[t]{2}{*}{ Unit Operation } & \multicolumn{5}{|c|}{ 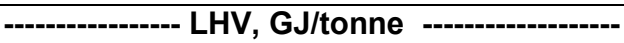 } & \multicolumn{5}{|c|}{ |- } \\
\hline & Gas & Steam & Losses & Electricity & Heat & Gas & Steam & Losses & Electricity & Heat \\
\hline Reformer Feed & 20.4 & & & & 20.4 & 19.4 & & & & 19.4 \\
\hline Reformer Fuel & 9.9 & & & & 9.9 & 9.4 & & & & 9.4 \\
\hline Primary reformer & & 4.8 & & & 4.8 & & 4.1 & & & 4.1 \\
\hline Secondary reformer & & 0.0 & & & 0.0 & & 0.0 & & & 0.0 \\
\hline Waste heat Boiler & & -5.6 & & & -5.6 & & -4.8 & & & -4.8 \\
\hline Shift $+\mathrm{CO} 2$ removal & & 1.2 & & 0.2 & 1.2 & & 1.0 & & 0.2 & 1.0 \\
\hline Methanator & & & 0.3 & & 0.3 & & 0.0 & 0.2 & & 0.2 \\
\hline Synthesis loop & & -2.0 & & 0.2 & -2.0 & & -1.7 & & 0.2 & -1.7 \\
\hline Aux. Boiler & 4.5 & -3.9 & & & 0.6 & 4.2 & -3.3 & & & 0.9 \\
\hline Turbines/Compressor & & 5.5 & & & 5.5 & & 4.7 & & & 4.7 \\
\hline Miscellaneous & & & 0.3 & 0.1 & 0.3 & & & 0.3 & 0.1 & 0.3 \\
\hline Flare & 0.3 & & & & 0.3 & 0.3 & & & & 0.3 \\
\hline Total & 35.0 & 0.0 & 0.6 & 0.5 & 35.6 & 33.4 & 0.0 & 0.5 & 0.4 & 33.8 \\
\hline \multicolumn{11}{|l|}{ Summary } \\
\hline Feedstock & & & & & 20.4 & & & & & 19.4 \\
\hline Fuel & & & & & 15.2 & & & & & 14.4 \\
\hline Electricity & & & & $\mathrm{KWh} / \mathrm{t}$ & 0.5 & & & & $\mathrm{kWh} / \mathrm{ton}$ & 0.4 \\
\hline Final & & & & & 36.1 & & & & & 34.3 \\
\hline Primary (incl. feedstock) & & & & & 37.1 & & & & & 35.1 \\
\hline Primary (excl. feedstock) & & & & & 16.7 & & & & & 15.7 \\
\hline
\end{tabular}




\section{The Chlorine Industry}

This chapter reflects an in-depth analysis of the chlorine and alkaline industry. The chlorine and alkalines production is closely connected, due to the feedstock used (salt). This sub-sector is one of the most energy and electricity intensive industries. The U.S. is the world's largest chlorine manufacturer.

The major markets for chlorine are PVC (37\%), inorganic chemicals (22\%), other organic chemicals $(17 \%)$, propylene oxide $(7 \%)$, pulp and paper $(6 \%)$, water treatment $(6 \%)$, solvents $(5 \%)$. The major markets for caustic are: pulp and paper $(26 \%)$, soaps and detergents $(9 \%)$, propylene oxide $(9 \%)$, petroleum $(8 \%)$, water treatment $(6 \%)$, other organic chemicals $(13 \%)$, inorganic chemicals $(12 \%)$ (Florkeiwicz, 1998). These areas are expected to continue to grow, but below the historical rate of growth (CMA, 1996). In part, the slower growth is attributable the collapse of the Asian economies and to environmental concern about the use of chlorine in industrial processes (Hileman et al., 1994).

In this chapter we first discuss the major process used to make chlorine (section 5.1), followed by a discussion of the U.S. chlorine industry (section 5.2) and energy consumption and intensity (section 5.3).

\subsection{Chlorine manufacturing Processes}

The production of chlorine gas is an energy intensive chemical process requiring between 25-40 GJ (worldwide average) primary energy per tonne chlorine produced (Phylipsen et al., 1998a). In the process a brine solution is converted into two co-products through electrolysis: chlorine gas and sodium hydroxide (caustic soda). The three main electrolysis cell types that are used to separate and produce the chlorine gas and caustic are the mercury flow, diaphragm, or ionselective membrane. In the diaphragm and membrane cells the caustic soda requires an additional step of concentrating the solution so that it can meet market specifications for most products. Of the three cell types the membrane cell requires the least energy to operate and is currently considered the state-of-the-art technology. Figure 7 shows the main process stages for chlorine production.

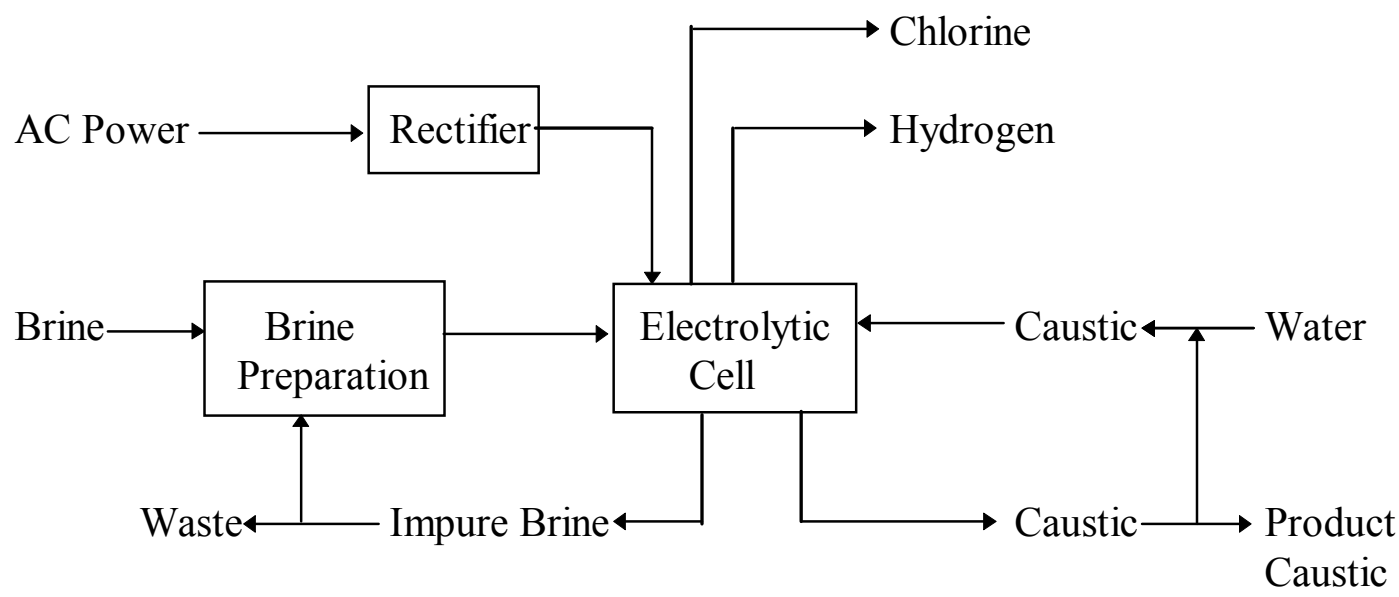

Figure 7. Simplified Chlorine Production Flow Chart 


\subsection{The U.S. Chlorine Industry}

Figure 8 below shows the age distribution of US chlorine plants. As the figure shows, most of the plants are 20-25 years old, and some considerably older. Appendix C provides data on chlorine production by plant and cell type for the US in 1994. As the table indicates there were 24 companies engaged in chlorine production with a total cell capacity of 11,525 Ktonnes. Some of the largest companies include Dow, Occidental, PPG Industries, and Olin with a share of total capacity of $27 \%, 25 \%, 13 \%$, and $7 \%$ respectively. The vast majority $(83 \%)$ of production took place in the South, where companies are able to take advantage of low electricity prices and low labor costs. Total capacity utilization in 1994 was $95 \%$. A total capacity of 2.1 million tonne/year is expected to come on line by 2000 in the US (Westervelt, February 25, 1998).

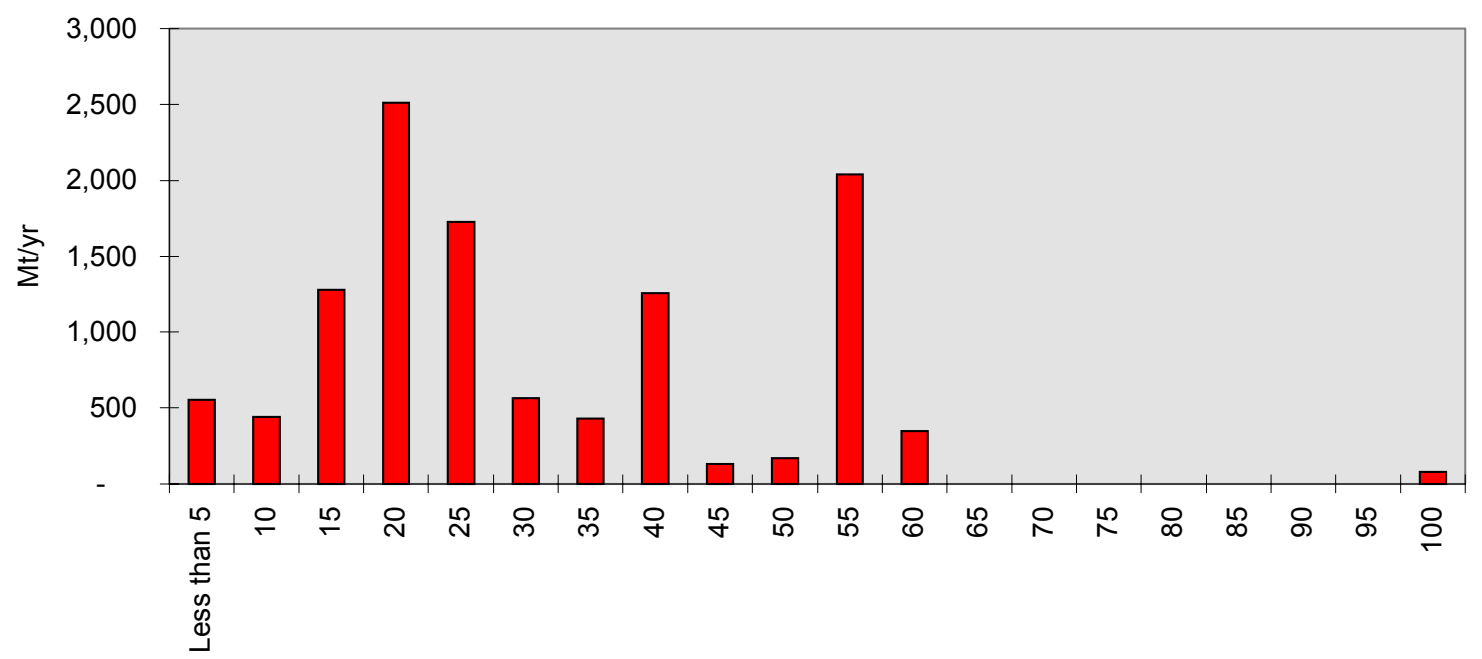

Figure 8. Age of U.S. Chlorine Plants. Source: SRI International, 1997

\subsection{Energy Use and Energy Intensity of Chlorine Making}

US energy statistics only report energy consumption for the chlor-alkali sector as a whole (which includes several products including chlorine) (SIC 2812) while excluding chlorine produced at an integrated facility where the final product is outside of the chlor-alkali sector (such as PVC). Therefore, in estimating 1994 baseline energy use and carbon emissions for the chlorine sector, we use available data to estimate the age and distribution of cell types in the US and estimate weighted average energy intensity, energy use, and carbon emissions. We also assume that cells which are 20 years old or greater are less efficient than new cells of the same type.

Table 17 identifies estimated final energy 15 consumption and carbon emissions in 1994 for chlorine/caustic production. Energy intensity estimates are calculated using a technological analysis of all three major technologies (mercury, diaphragm, and membrane). These analyses are based on energy consumption in a modern Dutch chlorine plant (Doesburg, 1994). This data is then combined with information on the market share of each of the technologies in the US (KirkOthmer, 1994). In addition, we assumed that chlorine plants constructed 20 years ago are 10\% less efficient than modern plants. Combining these two sources we calculate a weighted-average US energy intensity. The intensity values are multiplied by 1994 production estimates from the

\footnotetext{
${ }^{15}$ Final energy simply represents all the energy consumed at an industrial facility. Purchased electricity and steam are accounted by simple energy content as they enter the facility. This is in contrast to primary energy which includes the energy used to make that steam and electricity. All primary energy numbers in this paper assume electricity production is $40 \%$ efficient.
} 
Chemical Manufacturers Association to produce estimates of total consumption and carbon emissions. We estimate the specific electricity consumption at $4380 \mathrm{kWh} /$ tonne and specific fuel consumption at $3.45 \mathrm{GJ} /$ tonne. Net primary energy consumption is estimated at $47.9 \mathrm{GJ} /$ tonne, crediting the energy content of hydrogen export at $3.35 \mathrm{GJ} /$ tonne chlorine. For these calculations total energy use has been allocated to chlorine production.

Table 17. Chlorine Industry Energy Use and Carbon Dioxide Emissions. Sources: Doesburg (1994); CMA (1996); Kirk-Othmer (1994).

\begin{tabular}{|c|c|c|c|c|c|c|c|}
\hline \multirow[t]{2}{*}{ Process Stage } & \begin{tabular}{|c|} 
Final \\
Electricity \\
Intensity $^{\mathrm{a}}$ \\
\end{tabular} & $\begin{array}{c}\text { Fuel } \\
\text { Intensity }^{a}\end{array}$ & $\begin{array}{c}\text { Final } \\
\text { Energy } \\
\text { Intensity }^{\mathrm{a}}\end{array}$ & $\begin{array}{c}\text { Final } \\
\text { Electricity } \\
\text { Use }^{\mathbf{b}}\end{array}$ & $\begin{array}{l}\text { Final } \\
\text { Fuel } \\
\text { Use }^{\text {b }} \\
\end{array}$ & $\begin{array}{c}\text { Final } \\
\text { Energy } \\
\text { Use }^{\mathrm{b}}\end{array}$ & $\begin{array}{c}\text { Carbon } \\
\text { Emissions }^{\mathrm{c}}\end{array}$ \\
\hline & \begin{tabular}{|c|} 
GJ/tonne \\
$\mathrm{Cl}_{2}$
\end{tabular} & $\begin{array}{c}\text { GJ/tonne } \\
\mathrm{Cl}_{2}\end{array}$ & $\begin{array}{c}\text { GJ/tonne } \\
\mathrm{Cl}_{2} \\
\end{array}$ & PJ & PJ & PJ & KtC \\
\hline Rectifier & 0.28 & 0.00 & 0.28 & 3.1 & 0.0 & 3.1 & 132 \\
\hline Brine Preparation & 0 & 0.02 & 0.02 & 0.0 & 0.2 & 0.2 & 10 \\
\hline Cell Use & 13.63 & 0.00 & 13.63 & 149.6 & 0.0 & 149.6 & 6365 \\
\hline $\mathrm{NaOH}$ Concentration & 0 & 3.42 & 3.42 & 0.0 & 37.6 & 37.6 & $435^{\mathrm{d}}$ \\
\hline $\mathrm{NaOH}$ Cooling & 0.27 & 0.00 & 0.27 & 2.9 & 0.0 & 2.9 & 125 \\
\hline Hydrogen Cooling/Drying & 0.58 & 0.00 & 0.58 & 6.4 & 0.0 & 6.4 & 272 \\
\hline Chlorine Cooling/Drying & 0.39 & 0.00 & 0.39 & 4.3 & 0.0 & 4.3 & 181 \\
\hline Chlorine Compression & 0.63 & 0.00 & 0.63 & 6.9 & 0.0 & 6.9 & 295 \\
\hline Total & 15.78 & 3.45 & 19.23 & 173.20 & 37.81 & 211.02 & 7817 \\
\hline Hydrogen Heating Value & & & $-3.35^{\mathrm{e}}$ & & & $-36.8^{\mathrm{e}}$ & - \\
\hline
\end{tabular}

${ }^{a} 1994$ Industry Final Energy Intensity based on a calculation of weighted energy use by cell type and plant age. Cells and intensities for a modern 1989 plant were: Membrane $(9.8 \mathrm{GJ} /$ tonne electricity, $0.5 \mathrm{GJ} /$ tonne fuel), Diaphragm (11.3 GJ/tonne electricity, 2.6 GJ/tonne fuel), Mercury (12.3 GJ/tonne electricity, 0.1 GJ/tonne fuel) (Doesburg, 1994). Shares of cell type for 1994 are: membrane 8\%, diaphragm 75\%, mercury $15 \%$. These are based on Kirk-Othmer, 1994 and currently exclude plants that manufacture chlorine from sources other than Sodium chloride (e.g. magnesium chloride). Using the 1989 efficiencies for each cell type, and an assumed 10\% efficiency improvement over 20 years, we calculated an efficiency for each plant and took a production weighted average.

${ }^{\mathrm{b}}$ Industry total energy use based on a production of $11.05 \mathrm{Mt}$ of chlorine in 1994. Electricity production from cogeneration is currently not included in the calculation due to lack of reliable data.

${ }^{\mathrm{c}}$ Carbon emissions are based on the following factors from EIA, 1995. Electricity 42.6 KtC/PJ, Oil 20.4 $\mathrm{KtC} / \mathrm{PJ}$.

${ }^{\mathrm{d}}$ This value assumes that half the hydrogen produced is used to concentrate the caustic. The rest is sold or used in other production processes.

${ }^{\mathrm{e}}$ This is the fuel value of hydrogen. It is listed as a negative because it represents energy that can be used to fuel other processes.

The US Manufacturing Energy Consumption survey reports a total final energy consumption in 1994 for the chlor-alkali industry of 136 PJ with a net electricity consumption of 49 PJ. The MECS also reports that if one includes onsite cogeneration, the total electricity consumption for the sector is $62 \mathrm{PJ}$ which is still lower than our total calculated electricity use in Table 17. Since MECS includes products we are not considering, and excludes some chlorine production, we have chosen to currently rely on our technical estimates for energy consumption. 


\section{Discussion and Conclusions}

The U.S. chemical industry is the largest in the world, and responsible for a large part of U.S. industrial production (11\% of U.S. manufacturing value added). It also consumes approximately $20 \%$ of total industrial energy consumption in the U.S. (1994), and contributes in similar proportions to U.S. greenhouse gas emissions. Surprisingly, there is not much information on energy use and energy intensity in the chemical industry available in the public domain. This report provides detailed information on energy use and energy intensity for the major groups of energy-intensive chemical products.

Ethylene production is the major product in terms of production volume of the petrochemical industry. The petrochemical industry (SIC 2869) produces an extremely wide variety of products, although most energy is used for a small number of intermediate compounds, of which ethylene is the most important one. Based on a detailed assessment we estimate fuel use for ethylene manufacture at $520 \mathrm{PJ}$ (LHV), excluding feedstock use. Ethylene production is responsible for approximately $34 \%$ of energy use in the petrochemical industry. Energy intensity is estimated at $26 \mathrm{GJ} /$ tonne ethylene (LHV), excluding feedstocks.

The nitrogenous fertilizer production is also a very energy intensive industry, producing a variety of fertilizers and other nitrogen-compounds. Ammonia is the most important intermediate chemical compound, used as basis for almost all products. In the U.S. ammonia is produced mainly from natural gas. Fuel use is estimated at 268 PJ (excluding feedstocks), while 368 PJ natural gas is used as feedstock 16 Electricity consumption is estimated at 14 PJ. We estimate the energy intensity of ammonia manufacture at $39.3 \mathrm{GJ} /$ tonne (including feedstocks, HHV) and 140 $\mathrm{kWh} /$ tonne, resulting in an estimated primary energy consumption of $40.9 \mathrm{GJ} /$ tonne (HHV), equivalent to $36.6 \mathrm{GJ} /$ tonne (LHV).

The third most important product from an energy perspective is the production of chlorine and caustic soda. Chlorine is produced through electrolysis of a salt-solution. Chlorine production is main electricity consuming process in the chemical industry, next to oxygen and nitrogen production. We estimate final electricity use at $173 \mathrm{PJ}(48 \mathrm{TWh})$ and fuel use of $38 \mathrm{PJ}$. Total primary energy consumption is estimated at $526 \mathrm{PJ}$ (including credits for hydrogen export). The energy intensity is estimated at an electricity consumption of $4380 \mathrm{kWh} /$ tonne and fuel consumption of $3.45 \mathrm{GJ} /$ tonne, if all energy use is allocated to chlorine production.

Our estimates are based on surveys of individual plants in the industry as well as engineering estimates on the basis of literature values and surveys. This introduces uncertainties in the results. However, we are not able to estimate the magnitude of the uncertainties. Comparison with other official energy consumption statistics is difficult due to the aggregation levels, as well as different sub-sector divisions used in the statistics and this report.

Compared to earlier studies (e.g. Brown et al., 1985; Lipinsky and Ingham, 1994) the current report provides a detailed baseline of energy use in these processes, based on a detailed assessment of the industry and technologies used. The report also provides breakdowns for energy use in the various production steps and unit-operations for recent estimates of the energy intensity of processes.

\footnotetext{
${ }^{16}$ Feedstock use in the ammonia industry may result in direct $\mathrm{CO}_{2}$ emissions, in contrast to the petrochemical industry, where most of the carbon in the feedstock is used in the chemical product.
} 
Funding Statement. This work was supported by the Climate Protection Division, Office of Air and Radiation, U.S. Environmental Protection Agency through the U.S. Department of Energy under Contract No. DE-AC03-76SF00098.

Acknowledgements. Numerous people contributed to the data collection for this study, as well as reviewed (parts of) this report and earlier draft reports. For their help with the data collection and analysis we wish to thank Harry Vroomen (The Fertilizer Institute), Thomas F. Florkiewicz (Oxytech, Inc.) and George Birchfield (Solomon Associates, Inc.). We also wish to thank Paul Ciccio, Gerard van Harten, Richard Alvarado (Dow Chemical), Paul Heurtevant (Formosa Plastic Corporation), Russel Hoch, William Kane, Charles Keffer, Mark Savoie, Jeffrey Swann, and Mark Weavil (Monsanto) for sharing their insights with us. Finally, we wish to thank the participants of the "Workshop on Carbon Reduction Technology Opportunities for Chemical Process Industries" (organized by American Chemical Society, American Institute of Chemical Engineers, Chemical Manufacturers Association, The Council for Chemical Research, U.S. Department of Energy and U.S. Environmental Protection Agency), held in Baltimore, MD, March 3-4, 1999. Despite their efforts errors may still exist in the report, for which the authors are solely responsible. 


\section{References}

Appl, M., 1994. "Die Entwicklung der Ammoniaktechnologie” Chemische Technik 346 pp.125-182 (1994).

Bonner \& Moore Associates, Inc., 1998a. "U.S. Ethylene Supply/Demand," September 1998, http//www.bonnermoore.com.

Bonner \& Moore Associates, Inc., 1998b. "Ethylene Feedstock Economic Outlook," August 1998, http//www.bonnermoore.com,

Brown, H.L., et al., 1985, “Energy Analysis of 108 Industrial Processes,” U.S.-DOE, Washington D.C.

Bureau of the Census, U.S. Department of Commerce (BOC). 1998. "Annual Survey of Manufacturers and Census of Manufacturers" (http://www.census.gov/econ/www/manumenu.html).

Bureau of Economic Analysis, U.S. Department of Commerce (BEA). 1998. "National Industry and Wealth Data". (http://www.bea.doc.gov/bea/dn2.htm).

Chauvel, A. and G. Lefebvre, 1989. Petrochemical Processes, Part 1: Synthesis Gas Derivatives and Major Hydrocarbons, Editions Technip, Paris, 1989.

Chem-Intell, 1997. "Chem-Intell Chemical Manufacturing Plants Database," Reed Tele-publishing, London, November 1997.

Chemfacts, 1991. "Ethylene \& Propylene," Reed Telepublishing, London, 1991.

Chemical and Engineering News, 1985. "Facts and Figures for the Chemical Industry," Chemical and Engineering News, June $10^{\text {th }}$ issue.

Chemical and Engineering News, 1995. "Production of Top 50 Chemicals Increased Substantially in 1994," Chemical and Engineering News 73: No. 15.

Chemical and Engineering News, 1996. "Growth of Top 50 Chemicals Slowed in 1995 From Very High 1994 Rate," Chemical and Engineering News 71: April $8^{\text {th }}$ issue.

Chemical and Engineering News, 1997a. "Facts and Figures for the Chemical Industry." Chemical and Engineering News 72, June 23 issue.

Chemical and Engineering News, 1997b, "Chemical and Engineering News Production Statistics," Chemical and Engineering News 72: No. 27.

Chemistry \& Industry, 1996, ""The Deep Sea Olefin Trade," Chemistry and Industry, 1, January 1996, pp.15-18.

Chemical Manufacturers Association, 1996. "U.S. Chemical Industry Statistical Handbook," CMA, Arlington, VA.

Chemical Market Reporter, 1998, "Ethylene Capacity is Increasing as Margins come under Pressure," Chemical Market Reporter, 10253 p.32 (1998).

Chemical Market Reporter, 1998b, "US Expected to have Advantage in Growing Petrochemical Market," Chemical Market Reporter, 5253 p.12 (1998).

Chlorine Institute, 1994. "North American Chlor-Alkali Industry Plants and Production Data Book," Chlorine Institute, Washington DC.

Di Cintio, R., M. Picciotti and V. Kaiser, 1993, "Ethylene plant energy analysis," in AIChE Spring National Meeting, Houston, April 1993. 
Doesburg, R. van. 1994. "Energiebesparing in de Nederlandse Chloor-Alkali Industrie," (Energy Savings I the Netherlands' Alkalies and Chlorine Industry, in Dutch), Dept. of Science, Technology \& Society, Utrecht University, The Netherlands.

Energy Information Administration, U.S. Department of Energy (EIA), 1988. "Manufacturing Energy Consumption Survey, 1985," Washington, DC: EIA

Energy Information Administration, U.S. Department of Energy (EIA), 1991. "Manufacturing Energy Consumption Survey, 1988," Washington, DC: EIA

Energy Information Administration, U.S. Department of Energy (EIA), 1994. "Manufacturing Energy Consumption Survey, 1991,". Washington, DC: EIA

Energy Information Administration, U.S. Department of Energy (EIA). 1996. "Emissions of Greenhouse Gases in the United States, 1995," Washington, DC: EIA. Report number DOE/EIA-0573(95).

Energy Information Administration, U.S. Department of Energy (EIA), 1997. "Manufacturing Energy Consumption Survey, 1994," Washington, DC: EIA

Environmental Protection Agency, Office of Enforcement and Compliance Assurance (EPA), 1995. "Profile of the Inorganic Chemicals Industry," Washington, DC.

Florkiewicz, T. F., 1998. "The Future of Diaphragm Cell Technology," Oxytech Systems, Chardon, OH.

Gielen, D.J., D. Vos, and A.W.N. van Dril, 1996, "The Petrochemical Industry and its Energy Use; Prospects for the Dutch Energy-Intensive Industry," Netherlands Energy Research Foundation (ECN), Petten, The Netherlands, 1996.

Hileman, B., J. Long, and E. Kirschner, 1994. "Chlorine Industry Running Flat Out Despite Persistent Health Fears," Chemical and Engineering News November, 21, 1994, pp.12-26.

Hydrocarbon Processing, 1994, "Latin America HPI outlook is varied according to CS study," Hydrocarbon Processing, January, pp.25-26 (1994).

International fertilizer Association, 1998. "Databank - Balances Nitrogen, USA,” IFA, Paris, France.

Kirk-Othmer, 1994. Encyclopedia of Chemical Technology. Interscience Encyclopedia, New York, NY.

Lipinsky, E. and Ingham, J.D., 1994. "Final Task Report on Brief Characterizations of the Top 50 U.S. Commodity Chemicals," A Pacific Northwest National Laboratory report submitted to the U.S. Department of Energy, Biological and Chemical Technology Research Program.

Lipinsky, E. and Wesson, R. 1995. "Characterization of the Top12 U.S. Commodity Polymers," A Pacific Northwest National Laboratory report submitted to the U.S. Department of Energy, Biological and Chemical Technology Research Program.

Los Alamos National Laboratory, 1996, "Membrane Systems for Energy-Efficient Separation of Light Gases," Los Alamos National Laboratory, http://refining.dis.anl.gov/novel, 16 October 1998.

Lurgi, 1987. “The Lurgi Route to Ammonia,” Lurgi GmbH., Frankfurt/Main, Germany, March 1987

Nielsen, A. (ed.), 1995. Ammonia : Catalysis and Manufacture, Berlin ; New York : Springer-Verlag, 1995.

Nitrex, 1989. Data originally of NITREX, Switzerland, provided by Hydro Agri Benelux S.A., Brussels, Belgium.

Office of Management and Budget, U.S. Executive (OMB). 1987. Standard Industrial Classification Manual. Washington, DC: US OMB.

Office of Technology Assessment, Congress of the United States (OTA), 1993. "Industrial Energy Efficiency," Washington, DC: U.S. Government Printing Office. 
Oil \& Gas Journal, 1998. "Worldwide Ethylene Capacity Grows in Spite of Warnings," Oil \& Gas Journal Special, 1396 pp.41-47 (1998).

Phylipsen, G.J.M., K. Blok and E. Worrell, 1998a. "Handbook on International Comparisons of Energy Efficiency in the Manufacturing Industry," Dept. of Science, Technology and Society, Utrecht University, Utrecht, The Netherlands.

Phylipsen, G.J.M., K. Blok and E. Worrell, 1998b. "Benchmarking the Energy Efficiency of the Dutch Energy-Intensive Industry; A preliminary Assessment of the Effects on Energy Consumption and $\mathrm{CO}_{2}$ Emissions," Dept. of Science, Technology and Society, Utrecht University, Utrecht, The Netherlands.

Pletcher, D. and Walsh, F. “The Chlor-Alkali Industry,” in Industrial Electrochemistry, $2^{\text {nd }}$ Ed., 1989.

Rhodes, A.K., 1994. "World Ethylene Capacity Tops 71 Million mt/y; recovery on horizon," Oil \& Gas Journal, 25 April (1994) pp.35-49.

Rhodes, A.K., 1997. "World Ethylene Capacity Jumped 5 Million Mt/y or 6.5\% in Past Year," Oil \& Gas Journal, May $19^{\text {th }}$ issue.

SRI International, 1997. "Directory of Chemical Producers," SRI, Menlo Park, CA.

Solomon, 1995. "Word-wide Olefins Plant Performance Analysis," Solomon Associates Ltd., Windsor, UK.

Solomon, 1998. "Analysis of Cracker Efficiency Performed for the Dept. of Science, Technology and Society, Utrecht University," Solomon Associates Ltd., Windsor (confidential).

Stratton, A., Hemming, D.F. and Teper, M., 1983. "Ethylene Production from Oil, Gas and Coal-Derived Feedstock," IEA Coal Research, London, United Kingdom.

United States Geological Survey, 1998. “Minerals Yearbook 1996”, USGS, Minerals Information, Reston, VA.

Vroomen, H., 1998. Personal communication from Harry Vroomen, based on The Fertilizer Institute's 1997 Production Cost Survey, The Fertilizer Institute, Washington, D.C.

Westervelt, R., 1998. "Chlor-Alkali Tries to Weather Asian Flu," Chemical Week, February 15, 1998.

World Energy Council, 1995. "Energy Efficiency Improvement Utilizing High Technology: An Assessment of Energy Use in Industry and Buildings," by: M. D. Levine, E. Worrell, L. Price, and N. Martin (editors). London: World Energy Council.

Worrell, E., and K. Blok. 1994. "Energy Savings in the Nitrogen Fertilizer Industry in the Netherlands," Energy 219 pp.195-20 (1994).

Worrell, E., J.G de Beer, A.P.C. Faaij and K. Blok, 1994a, 'Potential energy savings in the production route for plastics', Energy Conservation and Management, 1235 pp.1073-1085 (1994).

Worrell, E. R.F.A. Cuelenaere, K. Blok and W.C. Turkenburg, 1994b. "Energy Consumption of Industrial Processes in the European Union," Energy 1119 pp.1113-1129 (1994).

Zeppenfeld, R., E. Haidegger and W. Borgmann, 1993. "Olefins - Separation Processes for Fractionation," Hydrocarbon Technologies International 1993, Sterling Publications International Ltd. 



\section{Appendix A: Overview of U.S. Ethylene Plants (Situation End of 1997).}

\begin{tabular}{|c|c|c|c|c|c|c|c|c|c|c|c|}
\hline \multirow[t]{2}{*}{ Company } & \multirow[t]{2}{*}{ Location } & & \multirow{2}{*}{$\begin{array}{l}\text { Year of } \\
\text { start up }\end{array}$} & \multirow{2}{*}{$\begin{array}{c}\text { Ethylene } \\
\text { Capacity } \\
\text { (ktonne/a) }\end{array}$} & \multicolumn{6}{|c|}{ Feedstock Mix (\%) } & \multirow[t]{2}{*}{ Licensor, Remarks } \\
\hline & & & & & Ethane & Propane & Butane & Naphtha & Gas oil & Other & \\
\hline Amoco & Chocolate Bayou & TX & & 1,451 & $36 \%$ & $40 \%$ & $0 \%$ & $24 \%$ & $0 \%$ & & Braun? \\
\hline \multirow[t]{2}{*}{ Chevron } & Cedar Bayou & TX & & 681 & $25 \%$ & $40 \%$ & $5 \%$ & $30 \%$ & $0 \%$ & & Stone \& Webster \\
\hline & Port Arthur & TX & & 784 & $80 \%$ & $20 \%$ & $0 \%$ & $0 \%$ & $0 \%$ & & \\
\hline Concea Vista & Lake Charles & LA & 1968 & 430 & $100 \%$ & $0 \%$ & $0 \%$ & $0 \%$ & $0 \%$ & & $\begin{array}{l}\text { Lummus; Including expansion of 150kt in 1990; } \\
\text { Formerly Vista Chemicals }\end{array}$ \\
\hline \multirow[t]{4}{*}{ Dow } & Freeport & TX & & \multirow[t]{2}{*}{1,224} & $50 \%$ & $50 \%$ & $0 \%$ & $0 \%$ & $0 \%$ & & \\
\hline & Freeport & TX & & & $50 \%$ & $50 \%$ & $0 \%$ & $0 \%$ & $0 \%$ & & \\
\hline & Plaquemine & LA & & \multirow[t]{2}{*}{1,102} & $50 \%$ & $50 \%$ & $0 \%$ & $0 \%$ & $0 \%$ & & \\
\hline & Plaquemine & LA & & & $25 \%$ & $25 \%$ & $25 \%$ & $25 \%$ & $0 \%$ & & \\
\hline DuPont & Orange & TX & & 590 & $50 \%$ & $50 \%$ & $0 \%$ & $0 \%$ & $0 \%$ & & Lummus \\
\hline Eastman & Long-view & TX & & 675 & $30 \%$ & $50 \%$ & $5 \%$ & $15 \%$ & $0 \%$ & & Lummus/Kellogg? \\
\hline \multirow[t]{5}{*}{ Equistar } & Channelview & TX & & 873 & $5 \%$ & $5 \%$ & $5 \%$ & $40 \%$ & $45 \%$ & & Before 1997: Lyondell \\
\hline & Channelview & $\mathrm{TX}$ & & 873 & $5 \%$ & $5 \%$ & $5 \%$ & $40 \%$ & $45 \%$ & & Before 1997: Lyondell \\
\hline & Clinton & IA & 1968 & 435 & $95 \%$ & $5 \%$ & $0 \%$ & $0 \%$ & $0 \%$ & & $\begin{array}{l}\text { Kellogg; Before } 1997 \text { Quantum; Expansion } \\
\text { planned of 37kt in } 1997\end{array}$ \\
\hline & LaPorte & TX & 1991 & 789 & $80 \%$ & $20 \%$ & $0 \%$ & $0 \%$ & $0 \%$ & & $\begin{array}{l}\text { Before 1997: Quantum; Expansion planned of } \\
182 \mathrm{kt} \text { in } 1996\end{array}$ \\
\hline & Morris & IL & 1971 & 512 & $90 \%$ & $10 \%$ & $0 \%$ & $0 \%$ & $0 \%$ & & $\begin{array}{l}\text { Lummus; Before 1997: Quantum; Including } \\
\text { expansion of 32kt in 1996 }\end{array}$ \\
\hline \multirow[t]{2}{*}{ Exxon } & Baton Rouge & LA & 1973 & 882 & $0 \%$ & $0 \%$ & $0 \%$ & $0 \%$ & $0 \%$ & & Kellogg; Including expansion in 1993 \\
\hline & Baytown & TX & & 1,890 & $0 \%$ & $0 \%$ & $0 \%$ & $0 \%$ & $0 \%$ & & $\begin{array}{l}\text { Kellogg; Including expansion of 700kt in } 1997 \text { by } \\
\text { Lummus/Exxon }\end{array}$ \\
\hline Formosa Plastics & Point Comfort & TX & 1994 & 714 & $45 \%$ & $25 \%$ & $0 \%$ & $15 \%$ & $15 \%$ & & $\begin{array}{l}\text { Kellogg Millisecond; Expansion planned of 204kt } \\
\text { in } 1997\end{array}$ \\
\hline \multirow[t]{2}{*}{ Huntsman } & Port Arthur & TX & 1978 & 551 & $0 \%$ & $0 \%$ & $0 \%$ & $60 \%$ & $0 \%$ & $40 \% \mathrm{LPG}$ & Stone \& Webster; Before 1994: Texaco \\
\hline & Port Neches & TX & & 136 & $50 \%$ & $50 \%$ & $0 \%$ & $0 \%$ & $0 \%$ & RG & Scientific Design \\
\hline \begin{tabular}{|l} 
Javelina Co. \\
\end{tabular} & Corpus Christi & TX & & 108 & $0 \%$ & $0 \%$ & $0 \%$ & $0 \%$ & $0 \%$ & $100 \% \mathrm{RG}$ & \\
\hline \multirow[t]{2}{*}{ Mobil } & Beaumont & TX & 1975 & 566 & $70 \%$ & $24 \%$ & $6 \%$ & $0 \%$ & $0 \%$ & & $\begin{array}{l}\text { Stone \& Webster; Expansion planned of 250kt in } \\
1995\end{array}$ \\
\hline & Houston & TX & & 342 & $70 \%$ & $30 \%$ & $0 \%$ & $0 \%$ & $0 \%$ & & Kellog \\
\hline
\end{tabular}




\begin{tabular}{|c|c|c|c|c|c|c|c|c|c|c|}
\hline \multirow[t]{3}{*}{ Occidental } & Chocolate Bayou & $\mathrm{TX}$ & 1980 & 500 & $0 \%$ & $0 \%$ & $0 \%$ & $75 \%$ & $25 \%$ & Brown \& Root, Lummus \\
\hline & Corpus Christi & TX & 1980 & 773 & $15 \%$ & $30 \%$ & $0 \%$ & $35 \%$ & $20 \%$ & Stone \& Webster \\
\hline & Lake Charles & LA & 1986 & 364 & $50 \%$ & $50 \%$ & $0 \%$ & $0 \%$ & $0 \%$ & Lummus Crest \\
\hline Philips & Sweeny & $\mathrm{TX}$ & \multirow[t]{3}{*}{1978} & \multirow[t]{4}{*}{2,040} & $70 \%$ & $30 \%$ & $0 \%$ & $0 \%$ & $0 \%$ & \multirow[t]{3}{*}{ Selas, debottlenecking 1990} \\
\hline \multirow[t]{3}{*}{ Philips } & Sweeny & TX & & & $92 \%$ & $8 \%$ & $0 \%$ & $0 \%$ & $0 \%$ & \\
\hline & Sweeny & TX & & & $75 \%$ & $25 \%$ & $0 \%$ & $0 \%$ & $0 \%$ & \\
\hline & Sweeny & $\mathrm{TX}$ & 1990 & & $30 \%$ & $60 \%$ & $10 \%$ & $0 \%$ & $0 \%$ & $\begin{array}{l}\text { 1,000kt Braun, 1990; Including expansion of } \\
227 \mathrm{kt} \text { in } 1996\end{array}$ \\
\hline Rexene Prod. & Odessa & TX & & 230 & $50 \%$ & $50 \%$ & $0 \%$ & $0 \%$ & $0 \%$ & Expansion planned of 188kt in 1998 \\
\hline \multirow[t]{3}{*}{ Shell } & Deer Park & $\mathrm{TX}$ & & 952 & $10 \%$ & $0 \%$ & $0 \%$ & $60 \%$ & $30 \%$ & Kellog \\
\hline & Norco & LA & 1976 & 793 & $0 \%$ & $0 \%$ & $0 \%$ & $30 \%$ & $70 \%$ & Kellog \\
\hline & Norco & LA & 1976 & 535 & $50 \%$ & $0 \%$ & $0 \%$ & $50 \%$ & $0 \%$ & Kellog: Including expansion of 182kt in 1996 \\
\hline \multirow[t]{2}{*}{ Sun } & Brandenburg & $\mathrm{KY}$ & & 45 & $100 \%$ & $0 \%$ & $0 \%$ & $0 \%$ & $0 \%$ & Lummus \\
\hline & Marcus Hook & PA & & 102 & $0 \%$ & $0 \%$ & $0 \%$ & $0 \%$ & $0 \%$ & \\
\hline \multirow[t]{3}{*}{ Union Carbide } & Seadrift & TX & 1962 & 415 & $80 \%$ & $20 \%$ & $0 \%$ & $0 \%$ & $0 \%$ & \\
\hline & Taft & LA & 1978 & 680 & $30 \%$ & $30 \%$ & $0 \%$ & $40 \%$ & $0 \%$ & $\begin{array}{l}\text { Wulff/Lummus, restarted in 1989; expansion } \\
\text { planned of 318kt in } 1997\end{array}$ \\
\hline & Texas City & TX & & 680 & $0 \%$ & $60 \%$ & $10 \%$ & $30 \%$ & $0 \%$ & \\
\hline Union Texas & Geismar & LA & 1968 & 545 & $82 \%$ & $18 \%$ & $0 \%$ & $0 \%$ & $0 \%$ & Lummus \\
\hline \multirow[t]{2}{*}{ Westlake Pol. } & Calvert City & $\mathrm{KY}$ & 1964 & 170 & $0 \%$ & $100 \%$ & $0 \%$ & $0 \%$ & $0 \%$ & Braun; Before 1994: BF Goodrich \\
\hline & Lake Charles & LA & 1992 & 1,043 & $80 \%$ & $20 \%$ & $0 \%$ & $0 \%$ & $0 \%$ & $\begin{array}{l}\text { Kellog Millisecond; Including 590kt expansion in } \\
1997\end{array}$ \\
\hline Total & & & & 25,475 & & & & & & \\
\hline
\end{tabular}

$\mathrm{RG}=$ refinery gas 


\section{Appendix B: Ammonia Plants in the United States (1998 Situation)}

\begin{tabular}{|c|c|c|c|c|c|}
\hline Company & Location & State & $\begin{array}{l}\text { Capacity } \\
\text { (tonnes/year) }\end{array}$ & $\begin{array}{l}\text { Feed- } \\
\text { stock }\end{array}$ & Licensor/Construction \\
\hline Agrium Inc. & Borger & TX & 439,000 & NG & Kellogg, modernized in 1989 \\
\hline Air Products & Pensacola & FL & 46,000 & NG & Chemico \\
\hline Allied Signal & Hopewell & WV & 409,000 & NG & Kellogg, revamp in 1986 \\
\hline Ampro & Donaldsonville & LA & 386,000 & NG & \\
\hline \multirow[t]{7}{*}{ Arcadian } & Geismar & LA & 501,000 & $\mathrm{NG} / \mathrm{RG}$ & Kellogg \\
\hline & Clinton & IA & 237,000 & NG & $\begin{array}{l}\text { Haldor Topsoe. Original plant } 1963, \\
\text { expanded } 1982\end{array}$ \\
\hline & Augusta & GA & 576,000 & NG & Haldor Topsoe (or Braun) \\
\hline & La Platte & $\mathrm{NE}$ & 182,000 & NG & \\
\hline & Lima & $\mathrm{OH}$ & 523,000 & NG & Revamped 1971 and 1982 \\
\hline & Memphis & TN & 340,000 & NG & \\
\hline & Woodstock & TN & 356,000 & $\mathrm{NG}$ & Ammonia Casale \\
\hline Avondale Ammonia & Fortier & LA & 399,000 & NG & Kellogg \\
\hline Borden Chemical & Geismar & LA & 363,000 & $\mathrm{NG}$ & Chemico, revamp 1982 \\
\hline CF Industries & Donaldsonville & LA & $1,740,000$ & NG & Kellogg 1966/68, revamp 1988 \\
\hline $\begin{array}{l}\text { Coastal St. Helens } \\
\text { Chemical }\end{array}$ & St. Helens & OR & 85,000 & NG & \\
\hline Coastal Chem & Cheyenne & WY & 172,000 & $\mathrm{NG}$ & 1965 (31,000 tpy), revamp 1985/87 \\
\hline Cytec Industries & Avondale & LA & 385,000 & NG & \\
\hline $\begin{array}{l}\text { Dakota Gasification } \\
\text { Co. }\end{array}$ & Beulah & ND & 91,000 & n.a. & \\
\hline Du Pont & Beaumont & TX & 363,600 & $\mathrm{NG}$ & Kellogg, revamp 1986 \\
\hline \multirow[t]{6}{*}{ Farmland Industries } & Beatrice & $\mathrm{NE}$ & 255,000 & NG & \\
\hline & Dodge City & KS & 255,000 & $\mathrm{NG}$ & Kellogg \\
\hline & Enid & $\mathrm{OK}$ & 919,000 & NG & Kellogg \\
\hline & Fort Dodge & IO & 241,000 & NG & Kellogg \\
\hline & Lawrence & $\mathrm{KS}$ & 409,000 & NG & Kellogg \\
\hline & Pollock & LA & 459,000 & NG & Kellogg \\
\hline $\begin{array}{l}\text { Greenvalley } \\
\text { Chemical }\end{array}$ & Creston & IA & 33,000 & NG & \\
\hline IMC Agrico & Donaldsonville & LA & 482,000 & NG & Kellogg \\
\hline IMC Nitrogen Co. & East Dubuque & IL & 269,000 & $\mathrm{NG}$ & N-Ren \\
\hline J.R. Simplot Co. & Pocatello & ID & 93,000 & NG & Haldor Topsoe 1964, expansion 1977 \\
\hline Koch Industries & Sterlington & LA & $1,110,000$ & NG & $\begin{array}{l}\text { Kellogg, two units, second } 1977(379,500 \\
\text { tpy) }\end{array}$ \\
\hline LaRoche Ind. & Cherokee & $\mathrm{AL}$ & 159,000 & $\mathrm{NG}$ & Kellogg, modernized 1986 \\
\hline \multirow{3}{*}{$\begin{array}{l}\text { Missippi Chemical } \\
\text { Co. }\end{array}$} & Yazoo City & MS & 363,600 & NG & Kellogg, revamp 1986 \\
\hline & Donaldsonville & LA & 409,000 & NG & Kellogg \\
\hline & Donaldsonville & LA & 500,000 & $\mathrm{NG}$ & \\
\hline Monsanto & Luling & LA & 446,000 & NG & Kellogg \\
\hline Nitromite Fertilizer & Dumas & TX & 128,000 & NG & \\
\hline Shoreline Chem. & Gordon & GA & 31,000 & $\mathrm{H} 2$ & \\
\hline \multirow[t]{4}{*}{ Terra International } & Blytheville & $\mathrm{AR}$ & 364,000 & $\mathrm{NG} / \mathrm{FO}$ & Bechtel/Haldor Topsoe \\
\hline & Sergeant Bluff & IA & 319,000 & NG & Kellogg \\
\hline & Verdigris & $\mathrm{OK}$ & 955,000 & $\mathrm{NG}$ & Kellogg 1975, revamp 1986 \\
\hline & Woodward City & $\mathrm{OK}$ & 446,000 & $\mathrm{NG}$ & Haldor Topsoe \\
\hline \multirow[t]{2}{*}{ Unocal } & Finley & WA & 150,000 & NG & Restarted 1995 \\
\hline & Kenai & $\mathrm{AK}$ & $1,180,000$ & NG & 1968, expanded 1977 (two units) \\
\hline $\begin{array}{l}\text { Wil-Grow Fertilizer } \\
\text { Co. }\end{array}$ & Pryor & OK & 86,000 & NG & \\
\hline Total & & & $17,461,000$ & & \\
\hline
\end{tabular}

Notes: Feedstock: Natural Gas (NG), Refinery Gas (RG), Fuel Oil (FO), Hydrogen (H2) 
Appendix C. Chlorine Plants in the United States (situation end of 1997)

\begin{tabular}{|c|c|c|c|c|c|}
\hline Company & City & State & \begin{tabular}{|c|}
1994 \\
Capacity \\
(Kt/year) $^{\mathrm{a}}$ \\
\end{tabular} & \begin{tabular}{|c|} 
Age of \\
Process in \\
$1994 * b$ \\
\end{tabular} & Process $^{c}$ \\
\hline Ashta Chemicals & Ashtabula & $\mathrm{OH}$ & 36 & 31 & $\mathrm{KCl}$ electrolysis; mercury cell; $\mathrm{KOH}$ by-product \\
\hline BF Goodrich & Calvert City & KY & 109 & 28 & Salt; mercury cell; diaphragm \\
\hline Dow & $\begin{array}{l}\text { Freeport } \\
\text { Plaquemine }\end{array}$ & TX & 2,041 & $\begin{array}{l}54 \\
36\end{array}$ & $\begin{array}{l}\mathrm{MgCl} \text { containing brines; diaphragm and by-product of magnesium } \\
\text { metal production } \\
\text { Brine; diaphragm }\end{array}$ \\
\hline DuPont & Niagara Falls & NY & 77 & 96 & Downs; By-product of metallic sodium production \\
\hline Elf Atochem & Portland & OR & 169 & 47 & Salt; diaphragm \\
\hline Formosa Plastics & Baton Rouge & LA & 180 & 13 & Brine; diaphragm (upgraded in 1981) \\
\hline & Point Comfort & TX & 505 & 0 & Membrane \\
\hline Fort Howard & $\begin{array}{l}\text { Green Bay } \\
\text { Muskogee } \\
\text { Rincon }\end{array}$ & $\begin{array}{l}\text { WI } \\
\text { OK } \\
\text { GA }\end{array}$ & $\begin{array}{l}8 \\
5 \\
6 \\
\end{array}$ & $\begin{array}{l}26 \\
9 \\
4\end{array}$ & $\begin{array}{l}\text { Rocksalt; diaphragm } \\
\text { Rocksalt; membrane (upgraded 1985) }\end{array}$ \\
\hline GE & $\begin{array}{l}\text { Burkville } \\
\text { Mount Vernon }\end{array}$ & $\begin{array}{l}\text { AL } \\
\text { IN }\end{array}$ & $\begin{array}{l}24 \\
50\end{array}$ & $\begin{array}{l}7 \\
18 \\
\end{array}$ & $\begin{array}{l}\text { Membrane } \\
\text { Captive brine; diaphragm }\end{array}$ \\
\hline Georgia Gulf Corp. & $\begin{array}{l}\text { Plaquemine } \\
\text { Bellingham }\end{array}$ & $\begin{array}{l}\text { LA } \\
\text { WA } \\
\end{array}$ & \begin{tabular}{|l|}
410 \\
82 \\
\end{tabular} & $\begin{array}{l}19 \\
29 \\
\end{array}$ & $\begin{array}{l}\text { Captive brine; diaphragm } \\
\text { Salt; mercury cell } \\
\end{array}$ \\
\hline HoltraChem & $\begin{array}{l}\text { Acme } \\
\text { Orrington } \\
\end{array}$ & $\begin{array}{l}\mathrm{NC} \\
\mathrm{ME}\end{array}$ & $\begin{array}{l}48 \\
73 \\
\end{array}$ & $\begin{array}{l}31 \\
27 \\
\end{array}$ & $\begin{array}{l}\text { Salt; mercury cell } \\
\text { Salt; mercury cell } \\
\end{array}$ \\
\hline La Roche Holdings Inc. & Gramercy & LA & 181 & 36 & Brine; diaphragm \\
\hline Miles Inc. & Baytown & $\mathrm{TX}$ & 82 & 22 & By-Product $\mathrm{HCl} ; \mathrm{HCl}$ electrolysis \\
\hline Niachlor Inc. & Niagara Falls & NY & 218 & 7 & Brine; membrane (upgraded 1987) \\
\hline Occidental & $\begin{array}{l}\text { Convent } \\
\text { Corpus Christi } \\
\text { Deer Park } \\
\text { Delaware City } \\
\text { La Porte } \\
\text { Mobile } \\
\text { Muscle Shoals } \\
\text { Niagara Falls } \\
\text { Tacoma } \\
\text { Taft }\end{array}$ & $\begin{array}{l}\text { LA } \\
\text { TX } \\
\text { TX } \\
\text { DE } \\
\text { TX } \\
\text { AL } \\
\text { AL } \\
\text { NY } \\
\text { WA } \\
\text { LA }\end{array}$ & \begin{tabular}{|l}
279 \\
417 \\
347 \\
126 \\
480 \\
41 \\
132 \\
293 \\
195 \\
581
\end{tabular} & $\begin{array}{l}13 \\
20 \\
56 \\
29 \\
20 \\
3 \\
42 \\
20 \\
6 \\
19 / 8\end{array}$ & $\begin{array}{l}\text { Captive salt dome; diaphragm } \\
\text { Brine; diaphragm } \\
\text { Captive salt dome; mercury cell; diaphragm } \\
\text { Salt mercury cell } \\
\text { Captive salt dome; diaphragm } \\
\text { Mercury cell; KOH is produced; membrane (upgraded 1991) } \\
\text { Mercury cell; KOH is produced } \\
\text { Captive salt dome; diaphragm (upgraded 1974) } \\
\text { Rock salt; diaphragm; membrane (upgraded 1988) } \\
\text { Captive salt dome; diaphragm (upgraded 1975); membrane } \\
\text { (upgraded in 1986) }\end{array}$ \\
\hline Olin Corporation & $\begin{array}{l}\text { Augusta } \\
\text { Charleston } \\
\text { McIntosh } \\
\text { Niagara Falls } \\
\end{array}$ & $\begin{array}{l}\text { GA } \\
\text { TN } \\
\text { AL } \\
\text { NY }\end{array}$ & $\begin{array}{l}102 \\
230 \\
365 \\
82 \\
\end{array}$ & \begin{tabular}{|l|}
29 \\
32 \\
17 \\
34 \\
\end{tabular} & $\begin{array}{l}\text { Salt; mercury cell } \\
\text { Rock salt; mercury cell } \\
\text { Brine diaphragm (upgraded 1977) } \\
\text { Rock salt; mercury cell (upgraded 1960) } \\
\end{array}$ \\
\hline Oregon Metallugical Corp. & Albany & OR & 2 & 23 & Magnesium chloride; by-product of metallic magnesium \\
\hline Pioneer Chlor Alkali Co. & $\begin{array}{l}\text { Henderson } \\
\text { St. Gabriel } \\
\end{array}$ & $\begin{array}{l}\mathrm{NV} \\
\mathrm{LA}\end{array}$ & $\begin{array}{l}104 \\
160 \\
\end{array}$ & $\begin{array}{l}18 \\
24 \\
\end{array}$ & $\begin{array}{l}\text { Salt; diaphragm (upgraded 1976) } \\
\text { Salt; mercury cell }\end{array}$ \\
\hline PPG Industries & $\begin{array}{l}\text { Lake Charles } \\
\text { Natrium }\end{array}$ & $\begin{array}{l}\text { LA } \\
\text { WV }\end{array}$ & \begin{tabular}{|l|l}
1,126 \\
356 \\
\end{tabular} & \begin{tabular}{|l|}
$25 / 17$ \\
$36 / 10$ \\
\end{tabular} & $\begin{array}{l}\text { Brine; mercury cell (upgraded 1969); diaphragm (upgraded 1977) } \\
\text { Brine; mercury cell (upgraded 1958); diaphragm (upgraded 1984) } \\
\end{array}$ \\
\hline $\begin{array}{l}\text { Renco Group (Magnesium } \\
\text { Corp. of America) }\end{array}$ & Rowley & UT & 14 & 17 & Brine; by-product of magnesium metal production \\
\hline Vicksburg Chemical Co. & Vicksburg & MS & 33 & 32 & By-product of production of potassium nitrate from $\mathrm{KCl}$ \\
\hline Vulcan Materials Co. & $\begin{array}{l}\text { Geismar } \\
\text { Port Edwards } \\
\text { Wichita } \\
\end{array}$ & $\begin{array}{l}\text { LA } \\
\text { WI } \\
\text { KS } \\
\end{array}$ & $\begin{array}{l}243 \\
65 \\
239 \\
\end{array}$ & \begin{tabular}{|l|}
18 \\
27 \\
$19 / 11$ \\
\end{tabular} & $\begin{array}{l}\text { Brine; diaphragm } \\
\text { Salt; mercury cell; KOH is also produced } \\
\text { Brine; diaphragm (upgraded 1975); membrane (upgraded 1983) }\end{array}$ \\
\hline Weyerhaeuser & Longview & WA & 136 & 19 & Brine; diaphragm (upgraded 1975) \\
\hline TOTAL & & & 11,525 & $29^{\mathrm{d}}$ & \\
\hline Total Production & & & $10,973^{\mathrm{e}}$ & & \\
\hline
\end{tabular}

a. Capacity numbers taken from Directory of Chemical Producers (DCP), SRI International

b. Cell type data and year of plant upgrade taken from Chlorine Institute Pamphlet 10 (1994).

c. Process data taken from DCP

d. Capacity weighted average age

e. Chemical Manufacturers Association

*Time since last major upgrade 